\title{
Was the U.S. Crisis a Financial Black-Hole?*
}

\author{
Romain Ranciere (PSE \& CEPR) Aaron Tornell (UCLA)
}

March 2011 (First Draft: October 2010)

\begin{abstract}
This paper argues that the U.S. financial crisis is a new type of crisis: a "financial black hole." Financial black-holes are characterized by the breaking-up of credit market discipline and the largescale financing of negative NPV projects. In a theoretical model, we explain how the interaction of perceived government guarantees and the ability to issue catastrophe-bond-like liabilities generates financial black-holes. We then show that key facts of the recent U.S. crisis can simultaneously be rationalized by the financial black hole equilibrium: Between 2003 and 2006, the origination of catastrophe-loan type mortgages exploded, as well as the issuance of 'Private Label' mortgage backed securities that helped off-load them into the market. During the same period, there was a massive increase in the origination of mortgages to borrowers with limited repayment ability, absent a continuous increase in home prices. While this situation should have lead to an upward re-pricing of the risk associated with Private Label MBS, the contrary occurred and the spread on these securities actually declined. While each of these facts in isolation can be interpreted differently, the strength of the financial black-hole explanation is its ability to account for the combination of these key facts.
\end{abstract}

keywords: Financial Regulation, Bailout Guarantees, Financial Liberalization, Housing, Mortgage Loans, Mortgage Backed Securities (MBS), Collateralized Debt Obligations (CDOs), Financial Crisis, US Crisis of 2007-2008.

\footnotetext{
*Paper prepared for the 11th Jacques Polak Annual Research Conference at the IMF. We thank Giovanni Dell'Aricia, Joe Ostroy, Ayhan Kose, Augustin Landier and Pierre Olivier Gourinchas for helpful comments.
} 


\section{Introduction}

The recent U.S. crisis has shown that the financial system might occasionally go awry generating negative social returns. The U.S. experience stands in contrast with the experience of emerging markets following financial liberalization. These countries have also experienced financial crises-the so called ' 3 rd generation' or balance-sheet crises-and systemic risk-taking has been, on average, associated with higher long-run growth. ${ }^{1}$

Here, we argue that the recent U.S. crisis is a different kind of crisis that can be characterized as a financial black-hole, whereby there is a breakdown of financial discipline that results in a largescale funding of negative NPV projects. $^{2}$ We then link the break-down of discipline to loose financial regulation, and argue that while improving regulation to prevent financial black-holes is desirable, overregulating in order to prevent all financial crises is not.

The toxic cocktail that generates black-holes is the combination of perceived government guarantees and the ability to issue, without collateral, catastrophe-bond-like liabilities that promise to repay little in good states and a large amount in crisis states. Under this anything-goes regulatory regime with no limits on the type of liabilities that can be issued, financial discipline breaks down, and lending conditions are not determined by the profitability of investment projects, but by the expected generosity of bailout guarantees. Between 2003 and 2006, the U.S. economy exhibits many features of a black-hole equilibrium: a massive origination and securitization of new types of mortgages whose repayment structure resembles catastrophe-bonds; the large-scale funding of borrowers with low repayment ability; and the underpricing of systemic-crisis risk. A key difference with previous $3^{\text {rd }}$-generation crises is that while in both cases guarantees were present, credit booms prior to previous crises were characterized by large amounts of risky standard debt, not by catastrophe-bonds instruments.

We consider a model economy where financial frictions interact with bailout guarantees. In this economy there are safe and risky mortgage originators that obtain external financing through the issuance standard debt and catastrophe-bonds. Standard debt promises to repay a given amount in all states of nature, while a catastrophe-bond promises to repay nothing in good states and a large amount in crisis states. In this setup financial regulation determines the menu of liabilities that can be issued, and the type of originators to whom lenders can lend.

If bailout guarantees could be outlawed by irreversible decrees, regulation would not play a crucial role because lenders and borrowers would internalize the consequences of their decisions. ${ }^{3}$ However,

\footnotetext{
${ }^{1}$ See for instance Ranciere, Tornell and Westermann (2008), and Ranciere, Tornell and Vamvakidis (2010).

${ }^{2}$ According to Wikipedia "A black-hole is a region of space from which nothing, not even light, can escape... Despite its invisible interior, a black hole can be observed through its interaction with other matter."

${ }^{3}$ That is, there would be no need for intrusive financial regulation in a truly laissez-faire regime-i.e., a regime that limit itself to ensuring private agents abide by their bilateral financial contracts.
} 
guarantees are better viewed as the outcome of a political-economy game in which authorities are ex-post forced to grant bailouts to avoid a meltdown, but there is no pressure to grant a bailout when an idiosyncratic default occurs.

How should financial regulation be designed in such a world of endogenous bailout guarantees? An overly restrictive financial regime that aims at eliminating all traces of financial fragility by allowing debt issuance only by safe originators, limits credit access and reduces productive investment. A shift to a liberalized financial regime that allows lending to risky originators, but only allows standard debt, increases the issuance of risky mortgages, which is socially efficient even though it increases the incidence of crises. Importantly, in such regime, systemic bailout guarantees do not lead to a break-down of financial discipline: the financial system will self-regulate and fund only positive NPV mortgages, some of which might go bust. Discipline comes about because under standard debt: (i) promised repayments cannot be concentrated in a particular state of nature (e.g. crisis states), and (ii) bailouts are granted only in crisis states. These restrictions imply that lenders find it optimal to impose collateral constraints, which means that originators must risk their own equity, and so only positive NPV mortgages are funded.

As we described above, a black-hole arises if regulation removes all restrictions on the issuance of catastrophe-bonds. This is because with bailout guarantees, catastrophe-bonds allow originators to shift all their promised repayments to the crisis states without the need to post collateral. Thus, financial discipline breaks down: this anything-goes regime induces not only the funding of negative NPV mortgages, but it also induces 'safe' originators with positive NPV mortgages-that would otherwise never default-to over-leverage and take on insolvency risk via the excessive issuance of catastrophebonds.

In the empirical part of the paper, we show that between 2003 and 2006 the US economy exhibits the four predictions of our black-hole equilibrium. First, there was a massive increase of mortgages whose effective repayment structure resembles catastrophe bonds, e.g., interest-only and option-ARM mortgages. The share of these new type of mortgages in total origination increased from $0.2 \%$ in 2002 to over $25 \%$ in 2006 . Second, this new type of mortgages was securitized by an alternative securitization chain-from private label securitizers (PLSs) to CDO issuers. The share of PLS in mortgage issuances increased from $12 \%$ in 2002 to $46 \%$ in 2006. Third, there was a massive increase in mortgage-backed securities origination to borrowers with limited repayment ability in the absence of a continuos increase in house prices. The share of zero down-payment originations increased from $4 \%$ in 2002 to $31 \%$ in 2006. Fourth, the pricing of mortgage-related securities loaded with catastrophe risk appeared insensitive to the increase of systemic risk, reflecting the presence of systemic bailout expectations. 
The structure of the paper is as follows. Section 3 present our model. Section 4 introduces a simple extension of the model featuring securitization. Section 4 presents the empirics. Section 5 relates our analysis to alternative explanations of the financial crisis put forward in the recent literature. Section 6 concludes.

\section{The Model}

We set up a minimal mortgage-origination model that allows us to analyze the circumstances under which the financial system performs its disciplining function of allocating resources to productive activities, but blocks the funding of unproductive activities. In order to make the role of catastrophe bonds transparent, in this section we consider a setup where homebuyers get mortgages from originators, who fund themselves by selling bonds to investors. In the next section we open the box and consider the more realistic setup in which instead of simple bonds, originators repackage mortgages into so called collateralized debt obligations (CDOs). Senior tranches of these CDOs, in combination with insurance instruments (credit default swaps (CDS)) are then purchased by regulated investors that most hold prime-grade securities in their balance sheets.

\subsection{Set-up}

Originators extend one-period mortgages to homebuyers that will repay the mortgage next period by using two sources of funds: a refinancing loan and his disposable income $y^{i}$. Thus, a homebuyer will repay the mortgage provided his disposable income plus the mortgage refinancing are greater than his committed mortgage repayment. Otherwise, the house will be foreclosed and the entire value of the mortgage will be lost in bankruptcy procedures.

Mortgages have a zero down payment and require the homebuyer to repay next period the loan plus the mortgage rate $\mu$, which includes a markup over the riskless rate $r$. The house price equals 1 at time $t$, and might go up or down at $t+1 .^{4}$

$$
p_{t+1}= \begin{cases}\bar{p}>1 & \text { with probability } u \\ \underline{p}<1 & \text { with probability } 1-u\end{cases}
$$

It follows that the time $t$ mortgage is 1 , the promised $t+1$ repayment is $[1+\mu]$, and the refinancing mortgage will equal $p_{t+1}$.

Homebuyers. There are three groups of homebuyers: safe, risky and no-doc. The safe homebuyers have a high and steady disposable income $\left(y^{\sigma}\right)$ that will allow them to repay the mortgage in full even

\footnotetext{
${ }^{4}$ Prices are exogenous in this paper. Ranciere and Tornell (2010) consider a dynamic model with endogenous prices.
} 
if house prices fall

$$
y^{\sigma}>1+\mu \text {. }
$$

The risky homebuyers have a random disposable income:

$$
y^{\theta}= \begin{cases}\widetilde{y} & \text { with probability } \theta \\ 0 & \text { with probability } 1-\theta\end{cases}
$$

A risky homebuyer is able to repay the mortgage if either home prices go up, or home prices go down, but he has positive income

$$
\bar{p}>1+\mu>\underline{p} \quad \text { and } \quad \widetilde{y}+\underline{p}>1+\mu
$$

The no-doc homebuyers will receive no income, and so they will repay the mortgage only if home prices go up and they obtain a refinancing mortgage.

It follows that there are three states in our economy: a good state $(\bar{s})$ in which all homebuyers can repay, a bad state $(\underline{s})$ in which only safe homebuyers can repay, and an intermediate state $\left(\bar{s}^{\prime}\right)$ in which both safe and risky homebuyers can repay, but no-doc homebuyers cannot repay.

$$
S_{t+1}=\left\{\begin{array}{lll}
\bar{s}: & p_{t+1}=\bar{p} & \text { probability } u \\
\bar{s}^{\prime}: & p_{t+1}=\underline{p} \text { and } y_{t+1}^{\theta}=\widetilde{y} & \text { probability }[1-u] \theta \\
\underline{s}: & p_{t+1}=\underline{p} \text { and } y_{t+1}^{\theta}=0 & \text { probability }[1-u][1-\theta]
\end{array}\right.
$$

Mortgage originators. There are three types of two-period lived mortgage originators $\{\sigma, \theta, \varepsilon\}$, each specializing in extending mortgages to one of the three homebuyers' types. Each young originator starts with internal funds $w_{t}$, and issues bonds with face value $b_{t}$, which are purchased by risk-neutral investors that have an opportunity cost $r$. The originator uses her funds in originating $I^{j}$ mortgages or buying a riskless bond that will repay $1+r$ next period. Thus, the budget constraint of a young originator is

$$
I_{t}+s_{t}=w_{t}+b_{t}
$$

At time $t$, a representative $j$-type mortgage originator lends 1 to a $j$-type homebuyer. At $t+1$ the $j$-homebuyer will repay $1+\mu$ if he is solvent or 0 otherwise. A $\sigma$-originator will get repaid for sure next period:

$$
q_{t+1}^{\sigma}=I^{\sigma}[1+\mu] .
$$

A $\theta$-originator will get repaid if either home prices go up, or home prices go down but $\theta$-homebuyers will receive a positive income

$$
q_{t+1}^{\theta}= \begin{cases}I^{\theta}[1+\mu] & \text { if } S_{t+1}=\left\{\bar{s}, \bar{s}^{\prime}\right\} \\ 0 & \text { if } S_{t+1}=\underline{s}\end{cases}
$$


An $\varepsilon$-originator will get repaid only if home prices go up. Since house prices and income are independent, the expected mortgage repayments are

$$
E\left(q_{t+1}^{\sigma}\right)=[1+\mu] I^{\sigma}, \quad E\left(q_{t+1}^{\theta}\right)=\zeta[1+\mu] I^{\theta}, \quad E\left(q_{t+1}^{\varepsilon}\right)=u[1+\mu] I^{\varepsilon},
$$

where the probability that $\theta$-homebuyers will repay their mortgages is

$$
\zeta:=u+[1-u] \theta
$$

We assume that extending mortgages to safe and risky homebuyers is a positive NPV undertaking, while mortgages to no-doc homebuyers is a negative NPV undertaking

$$
u[1+\mu]<1+r<\zeta[1+\mu]
$$

Safe homebuyers can be thought of as wealthy individuals that can always repay their mortgages. We can think of the risky homebuyers as workers with steady jobs that will be employed with a high probability $\theta$, while the no-doc homebuyers might not be employed. We can then interpret $\varepsilon$-mortgages as interest-only mortgages in which the required repayment is low during the first few years of the loan, but jumps up thereafter. As long as house prices will increase fast enough, the borrower will be able at that future date to get a new interest-only mortgage, and repay the original mortgage. This process can go on and on until house prices stop rising, at which point the borrower will default.

There are two types of liabilities that originators can issue: standard bonds and catastrophe bonds. Under a standard debt contract the borrower must repay next period in all states. If she is unable to repay debt, she defaults and all revenues are lost-in bankruptcy procedures. That is, under a standard debt contract the promised repayment is

$$
L_{t+1}^{s d}=b_{t}\left[1+\rho_{t}^{s d}\right] \quad \text { for all } S_{t+1},
$$

where $\rho_{t}^{s d}$ is the promised interest rate. Catastrophe bonds, in contrast, promise to repay a large amount in the bad state and zero otherwise

$$
L_{t+1}^{c b}= \begin{cases}0 & \text { if } S_{t+1}=\left\{\bar{s}, \bar{s}^{\prime}\right\} \\ b_{t}^{c b}\left[1+\rho_{t}^{c b}\right] & \text { if } S_{t+1}=\underline{s}\end{cases}
$$

The originator's profits will equal $q_{t+1}-L_{t+1}$ if the promised debt repayment $L_{t+1}$ is no greater than revenues $q_{t+1}$. If instead $q_{t+1}<L_{t+1}$, the originator defaults and all revenues are lost in bankruptcy procedures. It follows that expected profits are

$$
\pi_{t+1}^{j}=E_{t}\left(\max \left\{0, q_{t+1}^{j}-L_{t+1}^{j}\right\}\right) \quad j=\{\sigma, \theta, \varepsilon\}
$$




\section{Credit Market Imperfections}

The model economy includes two imperfections that capture two opposing forces: (i) financial frictions that might generate borrowing constraints; and (ii) bailout guarantees that might induce insolvency risk-taking, the financing of negative NVP projects and of diversion scams.

In our setup financial discipline arises because creditors impose borrowing constraints on mortgage originators. Thus, to analyze how bailout guarantees can lead to a break-down of financial discipline, it is necessary to endogeneize borrowing constraints. We do so by considering the following agency problem between originators and creditors.

Contract enforceability problems If an originator implements a diversion scheme at time $t$, she will be able to divert all funds at $t+1$ provided she is solvent. In order to implement a diversion scheme, the originator has to incur at time $t$ a diversion cost, proportional to her investable funds

$$
\text { diversion cost }=h\left[w_{t}+b_{t}\right]
$$

The parameter $h$ indexes the degree of contract enforceability. The greater $h$, the more costly for an originator to divert. An originator will choose not to set up a diversion scheme if and only if the expected debt repayment is less than the diversion cost

$$
\text { No diversion } \Leftrightarrow \text { originator's expected debt repayment } \leq h\left[w_{t}+b_{t}\right]
$$

To capture the stylized fact that bailouts are granted if there is a systemic financial crisis, but not otherwise, we consider the following bailout policy.

Systemic Bailout Guarantees If a majority of mortgages default, the government pays creditors of defaulting originators up to an amount $G_{t}=g w_{t-1}$ per creditor. If idiosyncratic defaults occur, creditors are not bailed out.

Financial Regulatory Regimes. Throughout the paper we say that the financial system performs its disciplinary role if all positive NPV mortgages are funded, but neither negative NPV mortgages nor diversion schemes are funded. In general, a sufficiently restrictive regulatory regime might succeed in inducing financial discipline, but at the cost of drastically reducing the availability of mortgage credit. In order to investigate the impact of a relaxation of financial regulation on mortgage-related activity and its effect on financial discipline, we consider three regulatory regimes.

Restrictive regime Only standard bonds can be issued. Investors can only buy safe bonds that will never default. 
Liberalized regime Only standard bonds can be issued. Investors can buy safe bonds and risky bonds that might default in some states of the world.

Anything-goes regime Any type of bonds can be issued. Investors can buy any type of bonds.

We would like to emphasize that since there are bailout guarantees, the anything-goes regime is distinct from laissez-faire. Under laissez-faire agents face the consequences of the contracts they sign. Not so under an anything-goes regime.

\section{Discussion}

While the insolvency risk faced by individual homebuyers is exogenous in our model, aggregate crisisrisk is endogenous. As we shall see, crisis-risk will depend on the type of mortgages that originators extend, the scale of their lending and the type of securities they issue. ${ }^{5}$

There a myriad ways to introduce financial frictions and bailout guarantees. In particular, one can postulate generous enough bailout policies that would destroy financial discipline even if borrowers were limited to issue only standard debt (i.e., there would be no discipline in any of the regulatory regimes described above). Such an exercise, however, would miss the key point that the set of permissible liabilities, drastically impact the ability to exploit bailout guarantees. This is why in order to carry out a meaningful analysis we need to restrict the class of bailout policies.

We impose discipline into our modeling by requiring that, under financial liberalization, the interaction between borrowing constraints and bailout guarantees can replicate the following stylized fact. Countries that experience rare balance-sheet crises tend to grow faster than countries with smooth growth paths and tight credit conditions. These $3^{\text {rd }}$-generation crises have characterized most emerging market crises in the last few decades, and have featured the issuance of standard debt not derivatives. ${ }^{6}$ To generate this stylized fact in our setup, it is necessary that under the restrictive and the liberalized regimes: (i) the financial friction gives rise to borrowing constraints; and (ii) bailout guarantees do not eliminate the discipline induced by borrowing constraints. Given that these requirements are satisfied, we will ask how is it that a shift to the anything-goes regime might lead to a breakdown of financial discipline.

Requirement (i) is satisfied in our framework because no-diversion condition (8) becomes a borrowing constraint only if it is binding in equilibrium for some positive $b_{t}$. This is the case only if at the margin the diversion cost is smaller than the expected interest cost. Thus, in order for the economy

\footnotetext{
${ }^{5}$ In a more elaborate set-up, borrower insolvency risk would endegously derive from mismatches between uncontingent promised debt repayments and contingent revenues (see Ranciere and Tornell, 2010.)

${ }^{6}$ Ranciere, Tornell and Westermann (2008), and Ranciere, Tornell and Vamvakidis (2010).
} 
to be financially constrained under standard debt we impose the following condition

$$
h<[1+r] \zeta
$$

Granting a bailout only if a critical mass of borrowers is in default is necessary for requirement (ii) because only in this case the no-diversion condition might become a borrowing constraint. If a bailout were granted in the wake of any idiosyncratic default, then lenders would not find it optimal to impose borrowing limits: (8) would never become a borrowing constraint. In addition to being crucial for the argument, we consider that this "systemic" nature of the guarantees is realistic. Typically, governments don't just grant a bailout whenever a default occurs. They do so only when the risk of an imminent meltdown generates enough political pressure. ${ }^{7}$

\subsection{Equilibria}

An implication of the systemic nature of the guarantees is that coordination-implicit or explicit-among agents, which results in correlated risks, is necessary for bailout expectations to arise in equilibrium. If a majority of agents do not expect a bailout under any circumstances, and these expectations are common knowledge, there are no incentives for any type of originator to unilaterally undertake insolvency risk.

In what follows we investigate when guarantees are activated, and we derive conditions under which a relaxation of the regulatory regime might increase productive investment without destroying financial discipline.

\subsubsection{Restrictive Regulatory Regime}

This regime requires that lenders lend only to $\sigma$-originators with access to the safe technology. Under such regime, financial fragility would arise and bailouts would be triggered only if originators issued excessive debt or they set up diversion schemes. The next proposition says that the are no incentives for such fragility-inducing actions.

Proposition 1 (Financial Discipline in a Restrictive Regime) Under the restrictive regulatory regime:

- The financial system performs its disciplinary role by imposing borrowing constraints that ensure diversion schemes are not profitable.

\footnotetext{
${ }^{7}$ For the endogeneity of bailout guarantees see Farhi and Tirole (2009), Chari and Kehoe (2010) and Schneider and Tornell (2004).
} 
- Systemic bailout guarantees are never triggered.

Consider the case where no bailout guarantees are expected. Lenders are willing to lend up to an amount that ensures originators will be able to repay debt and have no incentives to divert borrowed funds. Suppose for a moment that such a contract is feasible. Then lenders break even if the interest rate on debt equals the riskless rate

$$
1+\rho_{t}^{\text {safe }}=1+r
$$

It follows that the no-diversion constraint (8) is

$$
b_{t}[1+r] \leq h\left[w_{t}+b_{t}\right]
$$

This no-diversion constraint becomes a borrowing constraint because contract enforceability problems are severe enough: $h<1+r$ (this condition is implied by (9)). It follows that borrowing and investment are

$$
b_{t}^{s}=\left[m^{s}-1\right] w_{t}, \quad I_{t}^{s}=m^{s} w_{t}, \quad m^{s} \equiv \frac{1}{1-\frac{h}{1+r}}
$$

The first equation shows that credit is constrained by internal funds. The second equation exhibits the familiar financial accelerator: investment equals the multiplier times internal funds. As we can see, the greater the degree of contract enforceability $h$, the greater the investment multiplier.

To verify that borrowers will be able to repay we replace (12) in (7), and find that the borrowing constraint ensures that revenues will be sufficient to repay debt (i.e., profits are always positive (because $\sigma>h))$

$$
\pi_{t+1}^{\sigma}=\sigma m^{s} w_{t}-\left[m^{s}-1\right][1+r] w_{t}=[\sigma-h] m^{s} w_{t}
$$

Furthermore, under borrowing constraint (11) the originator does not gain by setting up a diversion

scheme: she would get $\pi_{t+1}^{\sigma \text {,div }}=\sigma m^{s} w_{t}-h\left[w_{t}+b_{t}\right]=[\sigma-h] m^{s} w_{t}$, which is the same as his payoff under no diversion (13).

Lastly, the reason standard debt induces financial discipline under a restrictive regime is the following. Since $\sigma$-homebuyers will repay their mortgages in all states, bailout guarantees will never be triggered. The only way a $\sigma$-originator would default is she issued debt in excess of $b_{t}^{s}=\left[m^{s}-1\right] w_{t}$, so that the originator would have incentives to implement a diversion scheme and default next period. However, in equilibrium, an investor would never give diversion incentives to an originator. If the investor were to do that, she would be neither repaid nor bailed-out.

\subsubsection{Liberalized Regime}

A shift from the restrictive to the liberalized regime allows lenders to lend to any type of originator, but it preserves the restriction that only standard debt can be issued. The key point, made by the 
following proposition, is that even in the presence of bailout guarantees, liberalization does not destroy financial discipline. The latter is preserved by the requirement that debt must be repaid in all states of nature. Thus, on financial discipline grounds, the existence of guarantees is not sufficient to justify an overly restrictive regulatory regime.

Proposition 2 (Financial Discipline in a Liberalized Regime) Under the financially liberalized regulatory regime-that restricts liabilities to standard debt contracts-

- There is a relaxation of borrowing constraints, relative to the restrictive regime.

- Systemic bailout guarantees do not undermine financial discipline: negative NPV projects are not undertaken, while all originators with positive NPV mortgages are funded and do not divert.

Since a relaxation of borrowing constraints leads to more investment in positive NPV mortgages, this result is associated with the stylized fact that countries that have experienced rare but severe balance-sheet crisis-and so exhibit a negatively skewed distribution of real credit growth-tend to grow faster than other countries.

Case a. No bailout guarantees are expected

The problem of a lender lending to a $\sigma$-originator is the same problem as the one under the restrictive regime, and so credit and investment are as in (12). Consider a lender that lends to a $\theta$-originator that extends mortgages to risky homebuyers. Since she will default with probability $1-\zeta$, lenders require an interest rate that allows them to break even

$$
1+\rho_{t}^{\text {risky,NG }}=\frac{1+r}{\zeta}
$$

Since the expected debt repayment by the originator is $\zeta b_{t}\left[1+\rho_{t}\right]$, the no-diversion constraint is

$$
\begin{aligned}
h\left[w_{t}+b_{t}\right] & \geq \zeta b_{t}\left[1+\rho_{t}\right] \\
& =b_{t}[1+r]
\end{aligned}
$$

A comparison of borrowing constraints (11) and (15) reveals that in a liberalized regime with no guarantees, the $\theta$-originator can borrow and invest the same amounts as the $\sigma$-originator under the restrictive regime (they are given by $b_{t}^{s}$ and $I_{t}^{s}$ in (12)).

How about $\varepsilon$-originators with access to negative NPV mortgages? Since their expected return is too low $(u[1+\mu]<1+r)$, in the absence of guarantees they prefer to invest their funds at the riskless rate rather than originate mortgages. 
To sum up, under a liberalized regime, in the absence of guarantees, the financial market imposes discipline into investment decisions: the interest rates charged to originators and the borrowing constraints imposed on them internalize the risks taken on by originators. Thus, only originators with positive NPV projects are funded.

\section{Case b. Bailout guarantees are expected}

In this case, lenders impose the same interest rate on risky $\theta$-originators as that for safe $\sigma$-originators. This is because from the lender's perspective loans to $\theta$-originators are safe: either they will be repaid by the originator if $S_{t+1}=\left\{\bar{s}, \bar{s}^{\prime}\right\}$ or by the government if $S_{t+1}=\underline{s}$. That is, the interest rate to risky borrowers reflects the guarantee

$$
1+\rho_{t}^{\text {risky, } G}=1+r
$$

Since the originator's promised debt repayment has an expected value $\zeta b_{t}\left[1+\rho_{t}\right]$, the no-diversion constraint is relaxed (relative to the no-guarantees case)

$$
h\left[w_{t}+b_{t}\right] \geq \zeta b_{t}[1+r]
$$

It follows that with generous guarantees, borrowing and investment by $\theta$-originators are

$$
b_{t}^{r}=\left[m^{r}-1\right] w_{t}, \quad I_{t}=m^{r} w_{t}, \quad m^{r} \equiv \frac{1}{1-\frac{1}{\zeta} \frac{h}{1+r}}
$$

By generous guarantees we mean that the upper limit on the bailout is high enough, so that it is not binding in a risky equilibrium

$$
G_{t+1}=g w_{t}, \quad g>\frac{1}{\frac{1}{h}-\frac{1}{\zeta} \frac{1}{1+r}}
$$

We impose this condition throughout the paper.

Shifting from a no-guarantees' regime to a guarantee's regime has two benefits for a $\theta$-originator: it reduces the interest rate from $\frac{1+r}{\zeta}$ to $1+r$, and it relaxes her borrowing constraint, which allows for greater leverage and mortgage origination (the investment multiplier increases from $m^{s}$ to $m^{r}$ ). This relaxation of borrowing constraints comes about because lower expected interest payments reduce the incentives to divert. By reducing the severity of the underlying financial friction, bailout guarantees act as an implicit investment subsidy. However, this subsidy can be cashed in only by taking on insolvency risk.

A $\theta$-originator can choose to store her equity $w_{t}$ rather than invest in the risky technology. In the former case she will get $w_{t}[1+r]$ for sure, while in the latter case the originator might default and loose her equity $w_{t}$. Thus, she will take on insolvency-risk only if the benefits are high enough so that $w_{t}[1+r]$ is lower than expected profits, which are

$$
\pi_{t+1}^{r i s k y, B G}=\zeta\left\{[1+\mu] m^{r} w_{t}-\left[m^{r}-1\right][1+r] w_{t}\right\}=[\zeta[1+\mu]-h] m^{r} w_{t} .
$$


The benefits of taking on risk outweigh the default $\operatorname{costs} \pi_{t+1}^{r i s k y, B G}>w_{t}[1+r]$ if and only if $h>$ $[1+r-\zeta[1+\mu]] \frac{\zeta}{1-\zeta}$. This inequality necessarily holds for all $h>0$ because risky mortgages have positive NPV $(\zeta[1+\mu]>1+r)$.

Do bailouts induce the origination of the negative NPV $\varepsilon$-mortgages in a liberalized regime? No. To see why, suppose that an $\varepsilon$-originator issues standard debt and originates $\varepsilon$-mortgages. A lender would set interest rate so that he break even: $[1-u][1-\theta]\left[1+\rho^{\varepsilon}\right]=1+r$, and lend her an amount that satisfies the no-diversion constraint $u b\left[1+\rho^{\varepsilon}\right] \leq h[w+b]$ and that allows the originator to repay in full in the good state $q_{t+1}^{\varepsilon}-b\left[1+\rho^{\varepsilon}\right] \geq 0$. Even though lenders are willing to lend to an $\varepsilon$-originator, she has no incentives to risk her funds $w_{t}$ because her opportunity cost is greater than her expected return. Thus, guarantees do not activate the inferior technology when financial regulation restricts liabilities to standard debt contracts.

\subsubsection{Anything-Goes Regime}

Under this regime investors can fund any class of originators, as in the liberalized regime. In addition, regulation allows not only for the issuance of standard debt, but also permits the issuance of catastrophe bonds with no collateral.

As detailed in the next proposition, discipline need not break down. It is only the toxic combination of the anything-goes regulatory regime with generous systemic bailout guarantees that breaks financial discipline and generates financial black holes. Absent bailout guarantees, under an anything-goes regime lenders would internalize the consequences of their lending decisions and only positive NPV project would be funded. That is, there would be no need for financial regulation in a truly laissez-faire regime.

Proposition 3 (Anything-Goes Regime) In an anything-goes regulatory regime, where catastrophe bonds can be issued without collateral, the disciplining role of the financial system is determined by the generosity of bailout guarantees:

- Financial discipline breaks down if bailout guarantees are generous: (i)negative NPV mortgages are funded; and (ii) originators that would otherwise have zero likelihood of default, take on insolvency risk via an excessive issuance of catastrophe bonds.

- In the absence of generous bailout guarantees there is financial discipline: (i)only positive NPV mortgages are funded; (ii) there is no diversion; and (iii)all catastrophe bonds issued are repaid for sure by the issuer.

Case a. No bailout guarantees are expected 
Recall that an issuer of a catastrophe bond receives $b_{t}^{c b}$ at time $t$ for a promise to repay $L_{t+1}^{c b}=$ $b_{t}^{c b}\left[1+\rho_{t}^{c b}\right]$ in the bad state and zero otherwise. In the absence of guarantees, no investor is willing to buy catastrophe bonds issued by either $\theta$-originators or $\varepsilon$-originators because it is known that they will default in the bad state. Therefore, the investor will be paid zero in all states for sure. An investor, however, is willing to buy a catastrophe bond issued by safe $\sigma$-originators up to an amount that satisfies the no-diversion condition $[1-\theta][1-u] b_{t}^{c b}\left[1+\rho_{t}^{c b}\right] \leq h\left[w_{t}+b_{t}^{c b}\right]$. Since the interest rate that allows the lender to break even is $\rho_{t}^{c b}=\frac{1+r}{[1-\theta][1-u]}$, the no-diversion condition implies that the largest loan amount consistent with no diversion is $b_{t}^{c b}=m^{s} w_{t}$. Notice that this amount coincides with the amount of standard debt that the $\sigma$-originator can issue (see (12)). Furthermore, her expected profits are the same under both types of liabilities. Thus, in the absence of guarantees, the $\sigma$-originator is indifferent between issuing catastrophe bonds and standard debt.

In sum, in the absence of guarantees a shift from a liberalized regime to an anything-goes regulatory regime does not undermine the disciplinary role of the financial system. In fact, if the relaxation of regulation leads to the issuance of catastrophe bonds, they will be repaid for sure by the issuer.

If we define laissez-faire as a situation with an anything-goes regulatory regime and the absence of guarantees, we can say that laissez-faire does not undermine the disciplinary role of the financial system. ${ }^{8}$

\section{Case b. Bailout guarantees are expected}

Recall that with a catastrophe bond the promised repayment is concentrated in the bad state, while it is zero otherwise. In the bad state, although an $\varepsilon$-originator will default, the lender expects to be repaid by the government. A key implication is that the disciplinary role of the financial system breaks down: the lender does not care whether the mortgage pool is profitable or the originator will set up a diversion scheme. Thus, contract enforceability problems do not give rise to borrowing constraints. Rather, if the bailout generosity is high enough $\left(g>g^{*}\right)$, the lender and the $\varepsilon$-originator find it profitable to enter a catastrophe debt contract that fully exploits the bailout guarantee: since the maximum bailout is $G_{t+1}=g w_{t}$ and it will be activated in the bad state (with probability $[1-u][1-\theta]$ ), the lender lends up to

$$
b_{t}^{c b}=\frac{[1-u][1-\theta]}{1+r} g w_{t} .
$$

The $\varepsilon$-originator sets the quantity of $\varepsilon$-mortgages equal to

$$
I_{t}^{\varepsilon}=\left[1+\frac{[1-u][1-\theta]}{1+r} g\right] w_{t} \quad \text { if } g>g^{*} \equiv\left[\frac{1+r}{u[1+\mu]}-1\right] \frac{1+r}{[1-u][1-\theta]}
$$

Condition $g>g^{*}$ ensures that the expected profits of originating $\varepsilon$-mortgages $\left(\pi_{t+1}^{\varepsilon, c b}=u[1+\mu][1+\right.$ $\left.\left.\frac{[1-u][1-\theta]}{1+r} g\right] w_{t}\right)$ are greater than the return of safe bonds $[1+r] w_{t}$.

\footnotetext{
${ }^{8}$ Opponents of restrictions on OTC derivatives trading have such a laissez-faire regime in mind.
} 
Will a $\theta$-originator issue standard debt or catastrophe bonds? If she issued catastrophe bonds, the borrowing constraint would be determined by the bailout guarantee not by the no-diversion condition. Thus, the $\theta$-originator could borrow up to $b_{t}^{c b, \theta}=\frac{[1-\theta][1-u]}{1+r} g w_{t}$, and her expected profits would be $\pi_{t+1}^{\theta, c b}=\zeta[1+\mu]\left[1+\frac{[1-\theta][1-u]}{1+r} g\right] w_{t}$. If instead she issues standard debt, the borrowing constraint is determined by the no-diversion condition-as in the liberalized regime-and so her expected profits are $\pi_{t+1}^{\text {risky, } B G}=[\zeta[1+\mu]-h] m^{r} w_{t}$, which were derived above. A comparison of these expected profits reveals that $\theta$-originators prefer to issue catastrophe bonds over standard debt if the bailout generosity is high enough $\left(g>g^{* *}\right)$

$$
g^{* *} \equiv\left[\frac{[[1-\theta][1-u] \zeta-h] m^{r}}{[1-\theta][1-u] \zeta}-1\right] \frac{1+r}{[1-\theta][1-u]} .
$$

Lastly, $\sigma$-originators also prefer to issue catastrophe bonds over standard debt if the bailout generosity is high enough $\left(g>g^{* * *}\right)$

$$
g^{* * *} \equiv\left[\frac{[\sigma-h] m^{s}}{u \theta}-1\right] \frac{1+r}{[1-u][1-\theta]} .
$$

If $g$ is high enough, it behooves a $\sigma$-originator to shift from a strategy that never defaults-and yields $\pi_{t+1}^{\sigma, s a f e}=[\sigma-h] m^{s} w_{t}$-into a strategy that leads to default in the bad state by issuing an excessive amount of catastrophe bonds, so that promised debt repayments in the bad state surpass revenues. The latter strategy yields an expected profit of $\pi_{t+1}^{\theta, c b}=u \sigma\left[1+\frac{[1-u][1-\theta]}{1+r} g\right] w_{t}$.

The essential reason for the breakdown of discipline across safe originators is that the $\sigma$-originator can increase her promised bad state debt repayment without having to increase her promised repayment in the other states.

\section{Opening the Box: Mortgage Securitization}

Here, we open the box by replacing the risk neutral investors with regulated investment funds that most hold prime-grade securities in their balance sheets, and by introducing a new group of agents that trade financial insurance instruments. This setup will not add any new insight, but will allow us to link the abstract concept of catastrophe bonds to financial instruments used in the real world, such as collateralized debt obligations $(C D O s)$ and credit default swaps $(C D S s)$. This link will allow us to connect the implications of a financial black-hole equilibrium to observable aspects of the recent US housing boom-bust cycle.

We introduce two additional risk neutral agents with an opportunity cost of capital $r$ : funds and insurers. Funds are risk neutral agents, with an opportunity cost of capital $r$, that are required by regulation to hold safe net positions in their balance sheets (i.e., they should be rated as prime-grade). Insurers specialize in trading put-like instruments. In particular, insurers trade put contracts that 
have a promised repayment of the form

$$
L_{t+1}^{c b}= \begin{cases}0 & \text { if } S_{t+1}=x \\ x & \text { if } S_{t+1} \neq x\end{cases}
$$

In our modified setup originators package the mortgages they originate into CDOs. A CDO is a bundle of mortgages with two tranches: a senior tranche that promises an interest rate $\rho$, and a junior tranche that has an equity-like payoff. That is, the senior tranche is the first to be repaid from the mortgage pool, and only after it gets repaid in full, the junior tranche receives what is left.

Originators sell to the regulated investment funds the senior tranche of the CDOs $\left(b_{t}\right)$ and keep the junior tranche $\left(w_{t}\right)$. In particular, a $\theta$-originator with internal funds $w_{t}$ that sells $b_{t}$ senior CDO tranches to the funds, originates at time $t$ an amount of $j$-mortgages equal to $I_{t}=w_{t}+b_{t}$. Next period, depending on the realization of the state $S_{t+1}$, the fund (that holds the senior CDO tranche) will receive either $b_{t}[1+\rho]$ or zero, while the originator (that holds the junior CDO tranche) will receives the difference between the mortgage pool repayments and the payment of the senior CDO tranche. ${ }^{9}$

In order to manufacture a prime-grade security that pays for sure $b_{t}[1+\rho]$ in all states next period, a fund can buy from insurers a put that promises 0 in states where the senior tranche of the CDO will pay off, and promises $b_{t}[1+\rho]$ in states where the senior tranche of the CDO will pay off will default. It follows that, from the funds' and the regulator's perspectives, the combination of a senior CDO tranche plus the put constitute a synthetic safe "AAA security" that will repay $b_{t}[1+\rho]$ in every state. Of course, this synthetic AAA security might have a very low expected return because of the cost of the puts. As we shall see, here is where systemic bailout guarantees will kick in.

Whether the synthetic AAA security can be manufactured is determined by the regulations on derivatives trading. Analogous to the original model, we consider three regulatory regimes.

Restrictive regime. Funds must hold prime-grade securities. No trade in options is allowed.

Liberalized regime. Funds must hold prime-grade securities. Insurers can only sell protective options to holders of standard debt.

Anything-goes regime. Funds must hold prime-grade securities. Insurers can enter into any option contract with no collateral.

\footnotetext{
${ }^{9}$ Notice that buying a senior CDO tranche is like buying a call option that will pay only in the good state. In the literature catastrophe bonds are sometimes assumed to be call-like instruments: they pay 0 in the bad state and a positive amount in the good state. In this paper catastrophe bonds are puts.
} 
Notice that in the liberalized regime puts only serve as a hedging instrument, and will allow originators to finance risky but positive NPV mortgages. This is not true in the anything-goes regime. As we shall see, under the latter, trade in puts will allow agents to finance negative NPV mortgages.

The rest of the setup is as in the original model. In particular, contract enforceability problems and systemic bailout guarantees are as described in Section 2.

\subsection{Equilibria}

Since the setup is isomorphic to the original model, we use the propositions of Section 2 to describe the equilibrium outcomes under the three regulatory regimes.

In the restrictive regime funds only buy CDOs issued by $\sigma$-originators and defaults do not occur. Thus, the interest rate of the senior CDO tranche $\rho$ is equal to $r$, the funds opportunity cost. Since the internal funds of the representative $\sigma$-originator are $w_{t}$, it follows that $I^{\sigma}=m^{s} w_{t} \sigma$-mortgages are originated. Since funds cannot buy CDOs formed with risky $\theta$-mortgages, even though they have positive NPV, only a small amount of $\theta$-mortgages are originated $\left(I^{\theta}=w_{t}\right)$. Finally, $\varepsilon$-originators choose no to originate $\varepsilon$-mortgages as they have a negative NPV.

A shift to the liberalized regime makes it possible for funds to manufacture the synthetic riskless security by combining a protective put that will pay-off $b_{t}[1+\rho]$ if $S_{t+1}=\underline{s}$ with a senior CDO tranche issued by $\theta$-originators.

To determine the price of this put notice that the bailout guarantee is activated in the bad state $\left(S_{t+1}=\underline{s}\right)$. In the bad state there are generalized defaults of $\theta$-mortgages and of insurers. Thus, the government ends up paying the promised repayments of the puts (CDSs) sold by insurers. Since insurers are risk neutral and competitive, the guarantee makes the time $t$ price of the protective CDSs go to zero. It then follows that the risk neutral funds will accept a rate of return on the CDO $\rho$ equal to the riskless rate $r$. The results in the original model then imply that a fund will buy $\theta$-CDOs up to an amount that makes the $\theta$-originator indifferent between diverting and not diverting: $b_{t}=\left[m^{r}-1\right] w_{t}$. Thus, $I^{\theta}=m^{r} w_{t} \theta$-mortgages are originated.

The $\theta$-originators find it optimal to originate $\theta$-mortgages because the expected return on their equity $\left(w_{t}\right)$ is greater than the riskless return: $\zeta[1+\mu]>1+r$. Lastly, under a liberalized regime $\varepsilon$-mortgages are not originated because the $\varepsilon$-originators' expected returns on their equity are lower than the riskless return: $u[1+\mu]<1+r$. In other words, the financial system performs its disciplinary role.

Under an anything-goes regime, any type of derivatives can be traded without the need to post collateral. Because there are no restrictions on the option contracts that can be traded, originators are able to de-facto shift all their promised repayments from the good state to the crisis state, and 
in this way manufacture synthetic catastrophe bonds. Because there are systemic bailout guarantees the puts necessary to manufacture these catastrophe bonds are dirt cheap. As a result it is profitable for regulated funds to buy such synthetic safe securities. In the appendix we show how a financial black-hole can arise, by describing an array of derivatives contracts that support the issuance of $\varepsilon$ mortgages with a negative NPV. Like in the original model, the lethal cocktail is the combination of systemic bailout guarantees and lax regulation that allows for the creation of catastrophe-bond-like instruments.

For future reference we sum-up the implications of the model in the next Corollary.

Corollary 4 (Financial black-hole) A financial black-hole develops if and only if (i)there are systemic bailout guarantees, and (ii)financial regulation allows for the issuance of catastrophe-bond-like securities without collateral requirements. If there is a shift to a black-hole equilibrium, we observe:

1. Origination. An increase in mortgages with catastrophe-bond-like profiles, i.e., with very low required repayments during the first years, followed by a jump in repayments in latter years.

2. Securitization. An increase in catastrophe-bond-like mortgage securitization vehicles-such as CDOs-and financial insurance instruments-such as CDSs.

3. Funding of negative NPV mortgages. An increase in the share of subprime and Alt- $A$ mortgages issued to borrowers with a low ability-or none-to repay in the absence of house-price increases.

4. Bailout Expectations: Financial insurance is underpriced and is insensitive to mortgage default rates.

\section{A Financial Black-Hole in the US}

Here, we provide evidence that supports the view that the U.S. 2008 crisis is a financial black-hole rather than a typical third-generation banking crisis. While this section does not include a formal econometric test of the model, we can nevertheless argue that the four implications of a financial black hole equilibrium, described in Corollary 4, are present in U.S. data between 2003 and 2006. In the next section we discuss whether alternative explanations for the U.S. crisis are also consistent with the data.

In a financial black-hole the disciplining role of the financial system breaks down. This makes possible the undertaking of unproductive investment projects, and in particular the issuance of mortgages to individuals that will not be able to repay them, except if house prices increase significantly 
(implication 3 in Corollary 4). Such negative expected NPV mortgages can be originated by structuring their repayments as catastrophe bonds that promise nothing in good states and concentrate repayments in crisis states (implication 1). A rational originator would extend such mortgages only if she could off-load them into the financial markets. This off-loading is done via securitizers that manufacture securities with catastrophe bond-like payoffs (implication 2). As a result, the proliferation of negative NPV mortgages with catastrophe bond-like structures goes hand in hand with the issuance of securitization vehicles that the market is willing to buy. Last but not least, why would investors buy securities that inherit the negative NPV of the underlying mortgages? One possibility is that they are irrational or ill-informed. Alternatively, they are rational but expect that creditors will be bailed out by the government in case of systemic defaults (implication 4). Table 1 provides summary evidence that the US economy between 2003 and 2006 exhibits these four implications of a financial black-hole equilibrium.

1. Emergence of mortgages whose payout structure resembles that of catastrophe bonds. These new mortgages allow for low initial payments by deferring principal repayments (interest-only) or by even letting the principal increase over time (option ARM) ${ }^{10}$ Low initial repayments must be followed by much larger repayments later on, except if a continuous increase in the price of houses allows borrowers to refinance. Panel A, shows that the share of these mortgages increased from only $0.2 \%$ of the total value of mortgage originations in 2002 to an astounding $25.5 \%$ in $2006 .{ }^{11}$

2. New securitization vehicles. Because the new type of mortgages were non-conformable, they could not be securitized by Fannie Mae and Freddie Mac. Instead they were securitized by Private-Label Securitizers (PLS). A vast share of private label mortgage securities were repackaged into Collateralized Debt Obligations (CDOs). As explained in later in this Section, these CDOs in conjunction with financial insurance instruments allowed the market participation of regulated investors. Panel B indicates that the share of private label issuances in total MBS issuances increased from $12.6 \%$ in 2003 to $45.6 \%$ in 2006. Furthermore, the boom in the issuances of CDOs and Home Equity Loans Asset Backed Securities paralleled closely the boom in Private Label issuances, as we will show below.

3. A massive increase in the origination of mortgage to borrowers with limited repayment ability in absence of a continuos increase in house prices. Panel $\mathrm{C}$ shows that mortgages originated

\footnotetext{
${ }^{10}$ Typically a maximum is set at $120 \%$ of the principal, after which borrowers need to start amortizing.

${ }^{11}$ The total value of mortgage originated was roughly the same in 2002 and 2006.
} 
without any down-payment experienced a dramatic increase from only $4 \%$ in 2002 to more than $30 \%$ in $2006 .^{12}$ Traditionally, borrowers without verifiable income documentation were required to put a substantial down-payment. This situation changed dramatically between 2002 and 2006 when the dollar share of borrowers with combined low documentation and no down-payment increased from $1 \%$ to $15 \%$ of total originations. Lastly, the non-prime (Alt-A and subprime) share in the total value of originations increased from $14 \%$ in 2002 to $48 \%$ in 2006 .

4. Underpricing of catastrophe risk in mortgage-backed securities. Between 2003 and 2006, as the quality of mortgage underwriting deteriorated, the risk-premia on securities loaded with mortgage risk actually went down. The spread over treasuries implied by the JP Mortgage MBS index went down from $2.2 \%$ in 2003 to $0.99 \%$ in 2006 . Over the same period, the spread on AAA (BBB) tranches of Private Label Mortgage Backed Securities went from 0.6\% (3.20\%) to 0.20\% (1.30\%). Furthermore, during 2005 and 2006, the pricing of catastrophe risk was insensitive to alarming signals of default waves in the riskier segment of the mortgage market.

The rest of this section provides more detailed evidence about these facts.

\section{Fact 1: Catastrophe-Bond-like Mortgage Instruments.}

The model's catastrophe bonds are abstract objects, not instruments that are directly observable. Here we provide indirect evidence by analyzing non-conventional mortgages with a payoff structure that is similar to the payoff of catastrophe bonds. As our model shows, the financing of such mortgages implies the existence of catastrophe-bond-like financing instruments along the securitization chain. These non-conventional mortgages include interest-only, negative-amortization and option-ARM loans and were for the most part developed by subprime lenders. Interest-only mortgages carry low interest rates for an initial period of 24, 36 or 60 months followed by a sharp increase afterwards as amortization starts. However, because agents are able to continuously refinance when house prices are going up, they can avoid amortizing in the good state of the world and keep rolling with low mortgage payments. Therefore, large net repayments are triggered only in the bad state of the world where house prices stop rising. In this case, the borrower is likely to default.

Figure 1 plots the combined share of interest-only and option-ARM mortgages in the aggregate US market, as well as the share of interest-only mortgages in the portfolio of New Century, one of the largest mortgage originators that went bust in 2007. From 0\% in 2003, the share of ARM and interest-only loans in the total number of originated mortgages went up to $26 \%$ in 2006 . The shift

\footnotetext{
${ }^{12}$ As a consequence. the average Loan-to-Value ratio on mortgages increased from $80 \%$ in 2002 to $90 \%$ in 2006 according to Inside Mortgage Finance.
} 
was even more dramatic for New Century, where the share of interest-only loans alone went from $0 \%$ in 2002 to $38 \%$ in $2006 .{ }^{13}$

\section{Fact 2: Securitization of Catastrophe-bond-like instruments and subprime/Alt-A loans}

The key determinant of whether originators can originate non-conventional and subprime mortgages is whether, down the food-chain, securitizers are willing to securitize them, and regulated investors are willing to buy them. Until 2003, the securitization market was dominated by the Government Sponsored Enterprises (GSEs) Fannie Mae, Freddie Mac and Government Enterprise Ginnie Mae. These agencies were regulated and had to satisfy standards on the loans they securitized: loans needed to be conventional (standard amortizing loans), and conforming (below a maximum loan amount limit). In particular, the GSEs could not securitize interest-only loans and Option-ARM loans. Starting in 2003 there is a significant shift from GSE securitization towards private-label securitizers (PLSs), whose market share went fro $12 \%$ in 2003 to $44 \%$ in 2006.

PLSs were mostly investment conduits owned by large financial institutions-Bear Stearns, Citigroup, JP Morgan, etc.-and were practically not subject to regulations on mortgage securitization. PLSs bought mortgages from originators, securitized them into mortgage backed securities (MBS), and then repackaged them into cascade-like instruments: Collateralized Debt Obligations (CDOs) for mortgages, and Asset Backed Securities (ABSs) for home equity loans. Since the senior tranches of CDOs get paid first, some were rated 'prime-grade' by rating agencies, and could thus be purchased by regulated investors.

Figure 2 exhibits a stark correspondence between the origination of interest-only and option-ARM mortgages and the financial instruments that supported the origination of these catastrophe-bond like mortgages. As we can see there is a strong correspondence between the components of this food-chain, from the non-conventional mortgages to the issuance of private label mortgage-related securities, and ultimately to CDOs for mortgages and ABSs for home-equity loans. Figure 3 exhibits an even stronger correspondence between the same securities and the total value of subprime and Alt-A mortgages originations.

The tight correlation between the rapid increase of the issuances of non-conventional or non-prime mortgages and the rapid increase of instrument securitizing them validate the two first ingredient of our black hole equilibrium. The scale of the issuances is also an important factor. To see this notice that if only a few entrepreneurs issue catastrophe bonds, bailout expectations are likely to be absent. In this case, the financial system plays its disciplinary role and ensure the issuers of these catastrophe bonds have the ability and incentives to repay them. However, as the issuance of catastrophe bonds crosses some critical level and their combined risk becomes systemic, a tipping point might be reached

\footnotetext{
${ }^{13}$ See Landier, Saez and Thesmar (2010) for an analysis of the role of Interest-Only mortgages in New Century's fall.
} 
beyond which a perception of bailout guarantees is likely to arise. Between 2002 and 2006, the share of outstanding mortgages that have been securitized by Private Label Securitizers increases from $7.2 \%$ of GDP to $22 \%$ of GDP. ${ }^{14}$

\section{Fact 3: Funding of Negative Expected Net-Present Value Mortgages.}

Indirect evidence of the funding of negative net present value mortgages is provided by the shift of mortgage origination towards borrowers with both unverified income and little initial equity. These borrowers' repayment capacity depended critically on the continuous increase of home prices, like the no-doc borrowers of our model.

Figure 4 plots the dollar share of borrowers with a low level of income documentation and the dollar share of borrowers with no down-payments in the total value of mortgage originations between 2001 and 2006. During this period, the share of borrowers without down payments increased rapidly from $2 \%$ in 2001 to over $30 \%$ in 2006 . The share of borrowers with limited income documentation increased from $28 \%$ to $41 \%$. More interesting is the share of borrowers with both low documentation and no down payments since traditionally lenders would require a larger down payment to compensate for the extra risk associated with limited documentation on future income flows. Until 2003, the share of low-doc and no down payment remained low but increased sharply thereafter - precisely when the issuances of private labels MBS and CDOs boomed - and reached 15 percent in 2006.

Looking at the portfolio of New Century, one of the largest US mortgage originators that went broke in 2007, offers an even more dramatic view of the shift towards borrowers with low probability of repayment. Figure 5 presents the characteristics of New Century borrowers between 2002 and 2006 . The share of borrowers with no documentation-unverified stated income-increased from $25 \%$ in 2000 to $47.2 \%$ in 2006 .

An other way to gauge the shift towards borrowers with a lower repayment likelihood is to look at the relative share of prime and non-prime borrowing in mortgage issuances. Figure 6 plots the dollar share of conforming/prime mortgages and the combined dollar share of subprime mortgages, Alt-A mortgages and home equity loans. In addition the figure plots the share of Private Label MBS in the total of MBS issuances. Between 2003 and 2006, the share of more risky loans-subprime, Alt-A and Home Equity Line of Credit-increased dramatically from $15 \%$ to $48 \%$ while the share of prime mortgages declines sharply from $60 \%$ to $33 \%$. This means that in only 3 years a complete reversal occurs in which traditional loans (conformable/prime) were replaced by non-prime loans. Furthermore the share of non-prime mortgages in total mortgage origination displays an almost perfect correlation with the share of MBS issuances in total issuances.

\footnotetext{
${ }^{14}$ source: Flows of Funds and Bureau of Economic Analysis.
} 
One could ask: if house prices were expected to be on the rise, would subprime loans still have negative NPV? Of course, conditional on ever rising prices at a sufficiently high rate, the answer is no. But this is a very big IF. For instance, even in such an over-optimistic scenario, how would one evaluate the probability of repayment and therefore the rating of a loan to a low FICO individual with $0 \%$ collateral and with no income documentation? These type of questions are currently being addressed in the courts as many investors are trying to put back mortgage securitizers under the representation and warranties principle. Investors are arguing that originators misrepresented the shoddy quality of the mortgages they put into the securities they sold. The estimated losses for the securitizers range from $\$ 23$ billion to $\$ 180$ billion. ${ }^{15}$

The county-level analysis of Mian and Sufi (2009) offers additional evidence of the rise of negative NPV mortgages during the US boom (2002-2005). They partition U.S. counties into subprime and prime counties based on the 1996 fraction of subprime borrowers-i.e. with a FICO score inferior to 660-and find that between 2002 and 2005 subprime counties exhibited both a higher credit growth and a lower income growth than prime counties. This is evidence that mortgage credit was extended disproportionately more to counties with a larger share of borrowers with low repayment ability. Furthermore, these subprime counties also exhibited higher rates of mortgage securitization than prime countries. Ex-post, the disproportionately larger credit growth in counties with low income growth resulted in much higher default rates than in prime counties. These facts suggest an increase in the financing of negative NPV mortgages, that was fueled by securitization and resulted in much higher default rates.

\section{Fact 4: Catastrophic Risk underpricing and Systemic Bailout Guarantees.}

Systemic bailout guarantees are unobservable. Here, we present three facts that signal they have been present in the U.S.

First, as the model implies, in the presence of guarantees, puts against catastrophic risk are underpriced and are insensitive to increases in mortgage defaults. This underpricing of insurance instruments supports the issuance of CDOs. Figure 7 displays the dollar share of interest-rate only and option-ARM loans and the spread over treasury of the JP Morgan MBS Index, as well as the spread of the AAA and BBB tranches of Private Label Securitizers MBS. The figure makes clear the strongly negative correlation between the origination of catastrophe bond-like mortgages and the risk-premia on the bonds securitizing. The MBS market reaction to the increasing loading of catastrophe-risk was a reduction rather than an increase of risk-premia. This fact strongly support the existence of bailout expectations triggered by large-scale correlated risk.

Figure 8 plots the delinquency rates of subprime mortgages along with the spread-the insurance

\footnotetext{
${ }^{15}$ in Wall Street Journal, "Banks Face Another Mortgage Crisis," November 20, 2010.
} 
premium-implied by the CMBX.AAA index. This index corresponds to CDS contracts on either "AAA" CMBS bonds or on "AAA" tranches of CMOs. ${ }^{16}$ As we can see, until July 2007, the insurance premium was below $0.1 \%$, (a tenth of a percent), which means that these securities were considered almost as safe as US Treasuries in the very same period where defaults on subprime loans started to increase sharply. In fact, during 2006 and the first half of 2007, the spread actually declined from $0.1 \%$ to around $0.05 \%$. During the second half of 2007 the spread increased significantly but was only at around 100 bps in early November 2008 (after the failure of Lehman Brothers and the government take-over of AIG). It actually declined between August 2008 (1.5\%) and the end of October 2008 (1\%) before jumping up in the last two months of 2008. From the middle of 2009, as the rate of delinquency started to plateau, the CMBX spread started to mean-revert and went down to $0.8 \%$ in September 2010

Second, parallel to the insurance premium's insensitivity, the issuance of housing financing instruments was largely insensitive to early warning signals of abnormal default rates in the mortgage market. As we can see in Figure 9 the period of booming issuance of CDOs (2005-2007) corresponds to a period where delinquencies on subprime mortgages were trending up significantly (from 10\% in 2004 to $17 \%$ in 2007). A similar pattern is observed across the subset of more risky mortgages. Figure 10 shows that throughout 2005 and 2006 the share of subprime mortgages in total origination remained high, even though delinquency rates on these mortgages had already started to trend up.

Third, there was a measurable underlying political-economy rationale behind bailout expectations that derived from the government's mandates to foster home ownership among poor and minority households. ${ }^{17}$ In particular, since the mid-nineties Fannie Mae and Freddie Mac were directed to increase their purchase of mortgage backed securities that included loans to low income borrowers. In 1996, the government asked Freddie and Fannie to provide at least $42 \%$ of their mortgage financing to borrowers with income below the median in their area. This target was increased to $50 \%$ in 2000 and $52 \%$ in 2005. As a result, borrowing by minorities increased dramatically, as well as their rate of home ownership. Arguably, such mandates signalled that the government would not let a meltdown occur if house prices stopped growing.

Figure 11, left panel, plots the dollar share of loans issued to minorities in the total amount of mortgage originated in a given year. Between 1998 and 2006, the dollar share of loans extended to Hispanics almost tripled from $6.4 \%$ to $16.4 \%$ and the share of loans extended to African-Americans increased from $5.2 \%$ to $8.5 \%$. The volume of loans to African-Americans doubled while the volume of loans to whites increased by $50 \%$. Overall the share of minorities doubled from $12.5 \%$ in 1998 to

\footnotetext{
${ }^{16}$ These indexes are associated with commercial and multi-familty mortgage-backed securities.

${ }^{17}$ See Rajan (2010) for a political-economy analysis of the expansion of mortgage credit towards poor and minority households.
} 
$25 \%$ in 2006. Figure 7 right panel plots the rate of home ownership across the same ethnic groups and displays a mirror image of the distribution mortgage borrowing by race. Between 1996 and 2006, home ownership across Hispanic increased from $42 \%$ to $50 \%$ and home ownership across African-Americans increased from $44 \%$ to $48 \%$. The rate of home ownership of Whites increased in the same period from $69 \%$ to $72 \%$.

\section{Alternative Explanations of the US Crisis and Related Literature.}

We have detailed how several facts exhibited by the US economy between 2003 and 2006 are consistent with a financial black-hole equilibrium. A related question is how can the data tell apart our mechanism from alternative mechanisms put forward in the recent crisis literature. We argue that the strength of the financial black-hole explanation is its ability to account for the combination of the four key facts documented in the previous section. Of course, each fact in isolation could be interpreted differently.

Note first that our framework encompasses explanations based on the lack of regulation in the mortgage market and the ensuing relaxation of lending standards (Dell'Arricia, Igan, Laven, 2008). In fact, for a financial black-hole to emerge, a set of agents should be allowed to issue catastrophetype securities without collateral. If private label securitizers had been constrained by regulation to only securitize conventional amortizing mortgages subject to a minimum down-payment requirement, the extent of mortgage-related systemic risk taking would have been much more limited. ${ }^{18}$ The link between the lack of regulation in mortgage markets and the incentives to reduce lending standards is present in our framework. In addition, the break-down of market discipline is traced to the toxic combination of catastrophe bond-like securities and bailout expectations. The latter can explain the underpricing of systemic crisis risk and the lack of restrain in the issuances of risky mortgages and associated securities when warning signals of a potential meltdown emerged in 2005-2006.

An alternative explanation for the underpricing of systemic risk is the high degree of opacity and asymmetric information along the food chain of mortgage securitization in the orginate-to-distribute model (Gorton, 2010, Levitin-Wachter, 2010). While the lack of understanding of the underlying risk could be invoked for some class of investors (e.g., the German Landesbanks), this explanation is not really satisfactory for the large financial institutions that had sponsored private-label securitization

\footnotetext{
${ }^{18}$ A tighter regulation of PLS could have also prevented what Acharya et al. (2011) call a race to the bottom between GSEs and PLSs. Between 2003 and 2006, in the face of increasing competition from the PLSs and plagued by an accouting scandal (Farber (2010)), GSEs were pushed to lower their own securitization standards to maintain their revenues. GSEs also indirectly contributed to the development of PLS securitization by either purchasing Private Label MBS or selling credit protection against the default risk of PLS MBS. Between 2003 and 2006, the percentage share of Private Label securities in Fannie and Freddie portfolio quadrupled (Acharya et al., 2011.)
} 
and large-scale CDOs issuances. Many of them retained a significant exposure to mortgage related assets through investment conduits or other special purpose vehicles and made colossal losses during the crisis. ${ }^{19}$ Some other large financial institutions passed on mortgage-related credit risk to other investors through the purchase of credit default swaps protection from underwriters such as AIG. While the underpricing of systemic risk and the lack of provisioning by AIG can, in part, derive from asymmetric information on underlying mortgage-related risks, a more plausible explanation is that thank to its size, AIG enjoyed implicit bailout protection. Bailout expectations can also explain why buyers of CDS issued by AIG-the large financial institutions-did not require a large collateral buffer against potential large losses. Interestingly enough, these large financial institutions were right: during the crisis, the CDS counterparties of AIG were paid in full thanks to bailout money.

An other set of explanations focuses on the impact of cheap funding on excess risk-taking and a reckless relaxation of lending standards. Gourinchas (2010), and Caballero, Gourinchas, and Farhi (2008) argue that an important cause of the crisis is the imbalance between the global demand for liquid and safe assets and the limited supply of safe assets. These "safe assets" imbalances have helped reduce the US cost of funds and have provided incentives for US financial institutions to manufacture seemingly safe assets. We would argue that this excess demand for US assets is complementary to our mechanism as it contributed to scale-up the black-hole to very high levels, and conferred a global dimension to the recent financial crisis. In its absence, the black-hole might not have reached worldwide dimensions. We would also argue that an important root of the problem was US-grown. A large foreign demand for seemingly safe assets per-se does not seem sufficient to foster the emergence of the new types of mortgages and mortgage-related securities with catastrophe bond-like profiles. As mentioned earlier, while foreigners might have been less sophisticated investors that could have been fooled by the AAA stamp given to senior CDO tranches by complacent rating agencies, a significant fraction of investors were both sophisticated and domestic. ${ }^{20}$ In their case, bailout expectations are necessary to rationalize the underpricing of systemic risk.

Brunermeier (2009) argues that large financial institutions engaged in regulatory arbitrage by setting-up conduits-or SPVs-in order to invest massively in mortgage-backed securities without facing the standard bank capital requirements associated with risky investments. By doing so, they were

\footnotetext{
${ }^{19}$ There is evidence for example that Lehman Brothers moved even more aggresively in loading mortgage-related risk after the bailout of Bear Stearn in the spring of 2007 by doing outright purchases of mortgage portfolios in California and Florida. Underlying this investment move was the perception that a bailout was the worse possible outcome.

${ }^{20}$ Unfortunately there are no publicly available data on the relative shares of domestic vs. foreign holdings of Private Label MBS. If we look instead at holdings of Agency and GSEs backed securities, the foreign share increased from $8 \%$ in $11.3 \%$ in 2003 to $16.4 \%$ in 2006 and $19.5 \%$ in 2007 (source: Federal Flows of Funds) These figures make clear that while there was a rapid inflow of foreign money into the Mortgage-related securities, the vast majority of holdings remained domestic.
} 
able to replace relatively expensive capital by very cheap short-term funding in the money market using asset-backed commercial paper. After the onset of the crisis, the resulting maturity mismatch certainly played a key role in the rapid unfolding of the crisis - the run on conduits described by Gorton (2009) - and this is something we do not specifically capture with our framework. But beyond this point, the main effect of regulatory arbitrage was to boost the demand for non-GSEs mortgage-backed securities. This increased demand for mortgage-backed securities has certainly contributed to scale up the financial black-hole but cannot per-se explain: (i) the large scale origination of catastrophe bondlike mortgages and their securitization; nor (ii) the underpricing of systemic crisis-risk. Moreover, the ability of these conduits to engage in massive maturity mismatch was conditioned by the liquidity guarantee from their mother financial institutions, which in turn enjoyed implicit bailout guarantees (Farhi-Tirole, 2011). ${ }^{21}$ Indeed, as soon as the crisis erupted, bank guarantees were triggered and conduits' assets were brought back to the balance sheets of the large financial institutions that were bailed-out.

\section{Conclusions}

The recent US crisis brings to the fore the role of financial regulation in a world were bailout guarantees are an unavoidable feature of the financial landscape.

The wrong lesson to be drawn from the recent US crisis is that a reversal to financial repression is appropriate, on the grounds that financial liberalization plants the seeds of future crises. Trying to prevent all future crises might have the unintended consequence of hindering economy-wide growth, as well as rationing first-time buyers out from the housing market. We have argued that as long as the discipline of credit markets is maintained, financial liberalization helps improve productive efficiency and growth even if it leads to occasional crises. This is because it allows financially constrained agents to take on more risk and exploit profitable investment opportunities. This explains why emerging markets have, on average, reaped net growth benefits from liberalization despite the occurrence of crises. But we have also demonstrated that when liberalization is accompanied by unfettered deregulation, it can lead to a financial black-hole characterized by large scale funding of negative NPV projects. Giving free reins to financiers to issue large amounts of catastrophe bond-like securities, without posting appropriate collateral, it is like giving out a licence to kill the credit market discipline and to game the bailout guarantees. Between 2003 and 2006, the US economy exhibits the symptoms of the black-hole

\footnotetext{
${ }^{21}$ In Farhi-Tirole (2011), bailout guarantees induce correlated risks and crisis risk through maturity mismatch. In Acharya, Merhan and Thakor (2011) bailout guarantees can result in a looting equilibrium characterized by excessive leverage and the funding of negative NPV projects. In contrast with our paper, all the action in Acharya et al. (2011) is on the asset side of financial institutions and the issuance of catastrophe-bond like securities plays no role.
} 
decease: rapid development of catastrophe-bond like mortgages, securitized into catastrophe-bond like securities by unregulated financial institutions; large-scale funding of poorly secured and undocumented mortgage borrowers; and underpricing of the resulting systemic risk. Several other factors have made the black-hole even more fatal: an unsatiated demand for 'look-like safe' securities from the rest of the world, regulatory arbitrage and pervasive opacity throughout the financial sector.

The correct lesson to be drawn from the recent US crisis is that because it is impossible to outlaw bailout guarantees, financial liberalization must be accompanied by an efficient regulatory framework that prevents the excessive issuance of catastrophe bond-like securities without appropriate collateral. Such regulation faces two challenges.

First, it must be moderate enough so as to maintain agents' freedom to undertake risks in order to exploit profitable investment opportunities. ${ }^{22}$ Second, it must be general and nimble enough so as to allow regulators to track and curb the re-emergence of correlated catastrophic risks in yet undetermined areas of the economy, and the resulting issuance of catastrophe bond-like securities as soon as they reach a critical mass.

If regulation is not general and overarching enough, new agents outside the regulatory fence will pop up and issue catastrophe bond-like securities. \{They $\}$ Agents will likely be smart enough to correlate on the catastrophic risks they undertake and, in this way, game the implicit bailout

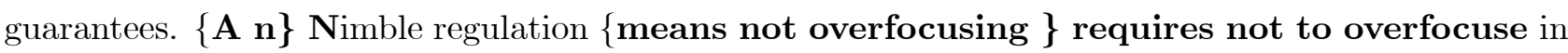
the design of 'scientific' tools, such as leverage indexes, that would be key in avoiding a crisis exactly like the one the U.S. experienced recently. Regulating to avoid the previous crisis is like shooting on a dead target, while preventing the next crisis is like being ready to shoot on a still hidden and moving target. It is unlikely that the next \{crisis $\}$ financial black-hole will originate in the real estate sector, which is going to be overregulated and overpoliced over the forseeable future. The future source of systemic risk will likely occur in an unregulated arena, and it is quite likely that it will feature correlated crisis-risk taking and an excessive issuance of catastrophe bonds. It will be clear ex-post, in the wake of the next crisis.

\section{References}

[1] Acharya V., Mehran H., A. Thakor, 2010, "Caught Between Scylla and Charybdis? Regulating Bank Leverage When There is Rent-Seeking and Risk-Shifting" mimeo NYU.

\footnotetext{
${ }^{22}$ If regulation is too restrictive, funding of profitable projects will dry up. Profitable projects are typically concentrated among small enterprises, who are the ones to suffer the fall in external finance.
} 
[2] Acharya V., Van Nieuwerburgh, S., Richardson, M., and L. White, 2011, "Guaranteed to Fail: Fannie Mae, Freddie Mac and the Debacle of Mortgage Finance", Princeton University Press.

[3] Brunermeier, M., 2009, "Deciphering the Liquidity and Credit Crunch 2007-2008", Journal of Economic Perspectives, 23(1):77-100

[4] Caballero R. \& Emmanuel Farhi \& Pierre-Olivier Gourinchas, 2008. "Financial Crash, Commodity Prices and Global Imbalances," Brookings Papers on Economic Activity, 2:1-55

[5] Coval, J., Jurek J., and E. Stafford, 2009, "The Economics of Structured Finance," Journal of Economic Perspectives, 23(1) 3-25,

[6] Dell'Ariccia, G., Igan, D., L. Laeven, 2008. "Credit Booms and Lending Standards: Evidence From The Subprime Mortgage Market," CEPR Discussion Papers 6683, C.E.P.R. Discussion Papers.

[7] Fannie Mae, 2008, "Fannie Mae 2008-10Q, Credit Supplement"

[8] Farber, David, 2010, And Then the Roof Caved In: How Wall Street's Greed and Stupidity Brought Capitalism to Its Knees, Wiley Publisher.

[9] Farhi E. and J. Tirole, 2011, "Collective Moral Hazard, Maturity Mismatch and Systemic Bailouts", American Economic Review, forthcoming.

[10] Gorton, Gary, 2010, "Slapped by the Invisible Hand: The Panic of 2007", Oxford University Press

[11] Gourinchas, P-0., 2010, "U.S. Monetary Policy, 'Imbalances' and the Financial Crisis", Testimony at the Financial Crisis Inquiry Commission, U.S. Congress.

[12] Landier, A., Sraer D., and D. Thesmar, 2008, "Going for broke:New Century Financial Corporation, 2004-2006", mimeo TSE.

[13] Levitin, A. and S. Wachter, 2010, "Explaining the Housing Bubble", mimeo Georgetown University

[14] Mian A. and A. Sufi, 2009, "The Consequences of Mortgage Credit Expansion: Evidence from the U.S. Mortgage Default Crisis," Quarterly Journal of Economics 124, 4.

[15] New Century Financial Corporation, 2008, Final Bankrupcy Report, http://graphics8.nytimes.com/packages/pdf/business/Final_Report_New_Century.pdf 
[16] Rajan, R., 2010, "Fault Lines: How Hidden Fractures Still Threaten the World Economy", Princeton University Press.

[17] Ranciere R. and Tornell, A., 2010, " Financial Liberalization, Boom-Bust Cycles and Production Efficiency", mimeo UCLA and PSE.

[18] Ranciere, R., Tornell A. and A. Vamvakidis, "Currency Mismatch and Systemic Risk in Eastern Europe," forthcoming, Economic Policy

[19] Rancière, R.,Tornell A. \&Westermann F., 2008. "Systemic Crises and Growth," The Quarterly Journal of Economics vol. 123(1):359-406 


\section{Appendix}

Black-hole in an Anything-goes Regime. Recall that in the setup of the Section 2 originators issue catastrophe bonds that promise to repay zero if $S_{t+1}=\left\{\bar{s}, \bar{s}^{\prime}\right\}$, and a high amount if $S_{t+1}=\underline{s}$. In the current setup, this repayment profile can be reproduced by the following array of CDOs and put contracts: (i) the $\varepsilon$-originator purchases from an insurer a put that promises $b_{t}[1+r]$ if $S_{t+1}=\left\{\bar{s}, \bar{s}^{\prime}\right\}$ and 0 if $S_{t+1}=\underline{s}$; (ii) the $\varepsilon$-originator pays the insurer with a put that promises $b_{t}[1+r] \frac{\zeta}{1-\zeta}$ if $S_{t+1}=\underline{s}$ and 0 otherwise; (iii) funds pay $b_{t}$ to $\varepsilon$-originators for a senior CDO tranche that promises $b_{t}[1+r]$ and the right to the payments of the put contract described in (i); lastly, (iv) funds buy from insurers a put that promises to pay $b_{t}[1+r]$ if $S_{t+1}=\underline{s}$ and 0 otherwise. ${ }^{23}$

At time $t+1$ the payoffs are as follows. If $S_{t+1}=\left\{\bar{s}, \bar{s}^{\prime}\right\}$, funds will receive $b_{t}[1+r]$ from insurers as payment for the put attached to the CDO, and so originators will pocket the mortgage repayments $[1+\mu]$ if $S_{t+1}=\bar{s}$. If instead $S_{t+1}=\underline{s}$, funds will get a bailout payment associated with their puts, and insurers will get a bailout payment associated with their put contract with originators. Since there are bailout guarantees, there are no collateral constraints and insurers are risk neutral, the price of these puts is zero. Thus, funds are willing to buy senior tranches of $\varepsilon$-CDOs that promise an interest rate $r$.

The upshot is that under this array of payoffs $\varepsilon$-originators are not required to make any net repayments if $S_{t+1}=\left\{\bar{s}, \bar{s}^{\prime}\right\}$. Thus, we obtain the same payoff structure as in the original model's anything-goes regime. As a consequence, the diversion constraint is not binding (because $0<h\left(w_{t}+\right.$ $\left.b_{t}\right)$ ). Therefore, funds set $b_{t}$ so as to maximize the bailout payment they will extract, disregarding the no-diversion constraint. Furthermore, notice that originators have incentives to originate $\varepsilon$-mortgages because they do not need to risk their own equity.

\footnotetext{
${ }^{23}$ Notice that under risk neutrality the time $t$ value of the put in (i) is $\zeta b_{t}[1+r]$, where $\zeta:=u+[1-u] \theta$. Meanwhile the the time $t$ value of the put in (ii) is $[1-\zeta] b_{t}[1+r] \frac{\zeta}{1-\zeta}$. It follows that both puts have the same time $t$ value.
} 
Table 1. Financial Black Hole Equilibrium: Key Facts.

\section{Panel A. Catastrophe-Loan type Mortgages}

Interest-Only +Option ARM Mortgage Loans (US\$ Bn)

$$
\% \text { of Mortgages Originated }
$$

\section{Panel B. Private Label Securitization}

MBS Issuance from Private Label Securitizers (US\$ Bn.)

$$
\begin{gathered}
\% \text { of Mortgages Originated } \\
\% \text { of MBS Issuances }
\end{gathered}
$$

Panel C. Negative NPV Mortgages

Loans with Zero Down payment (\% of Mortgage Originated)

Loans with Zero Downpayment and Low Documentation (\% of Mortgage Originated)

Non-Prime Mortgage Loans (\% of Mortgage Originated)

Panel D. Default-Risk Pricing

BBB Tranches of Private Label MBS (Spread over US Treasury)

\begin{tabular}{cc}
2002 & 2006 \\
5 & 760 \\
$0 \%$ & $26 \%$ \\
2002 & 2006 \\
290 & 917 \\
$10 \%$ & $31 \%$ \\
$13 \%$ & $46 \%$ \\
2002 & 2006 \\
$4 \%$ & $31 \%$ \\
$1 \%$ & $15 \%$ \\
$14 \%$ & $48 \%$ \\
& \\
\hline 2003 & 2006 \\
$3.20 \%$ & $1.30 \%$ \\
\hline
\end{tabular}

Source: Inside Mortgage Finances, Levitin-Wachter (2010), Mortage Banker Association 


\section{Figure 1. Originations of Interest-Only and Option-ARM Mortgage Loans}

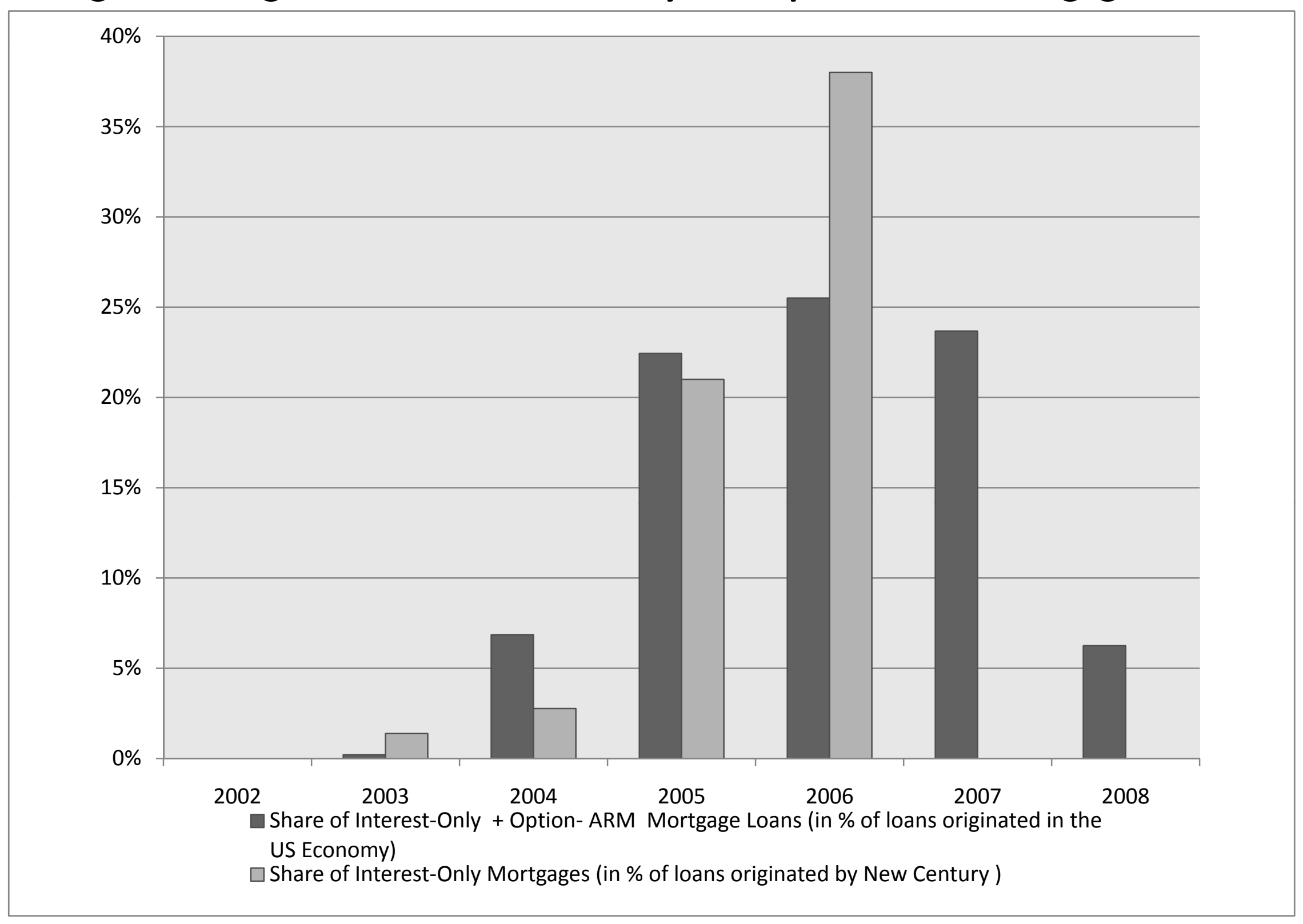




\section{Figure 2. Interest-Only and Option-ARM Loans, Private Label MBS and CDOs.}

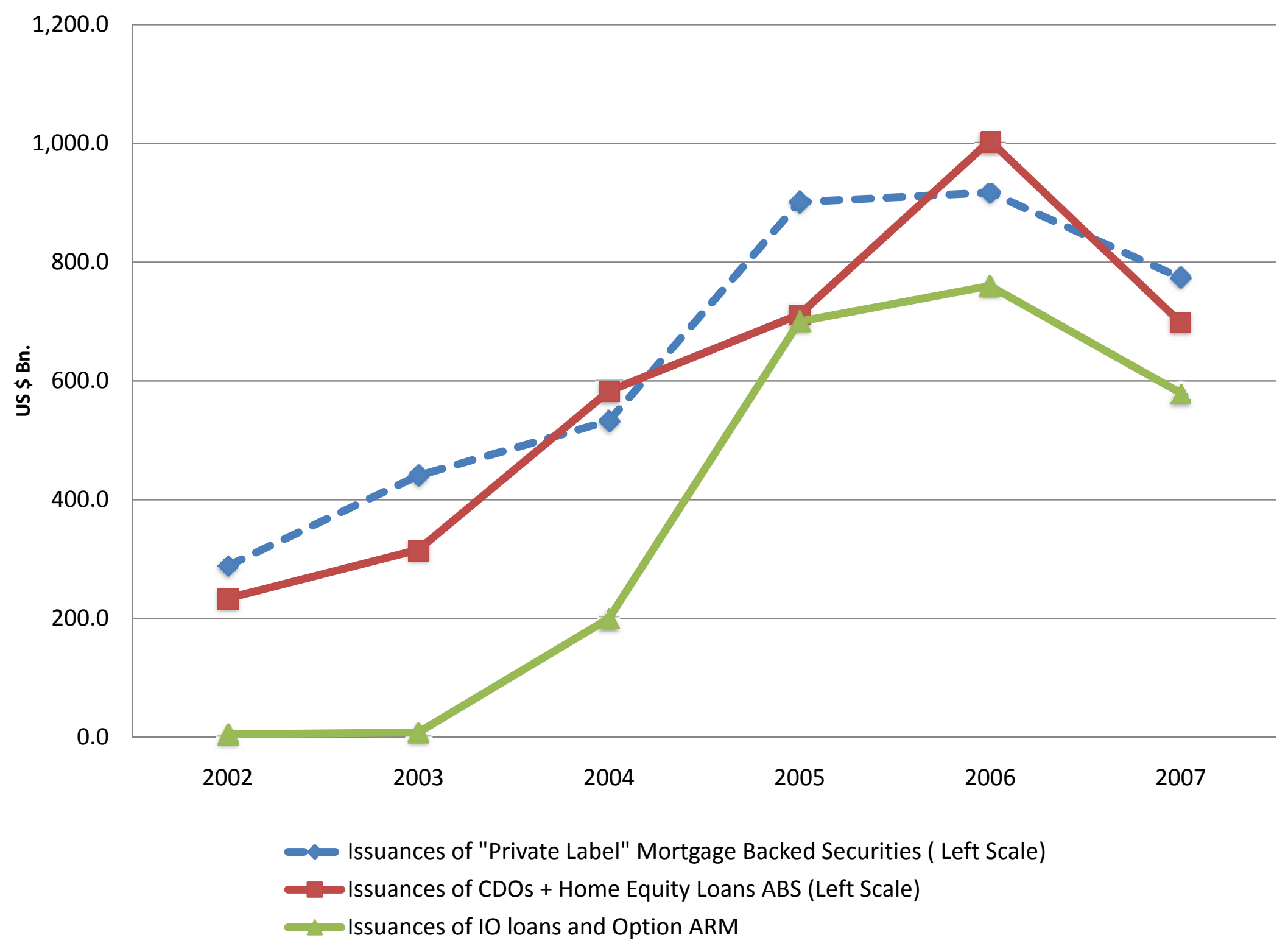


Figure 3. Subprime and Alt-A Loans, Private Label MBS and CDOs.

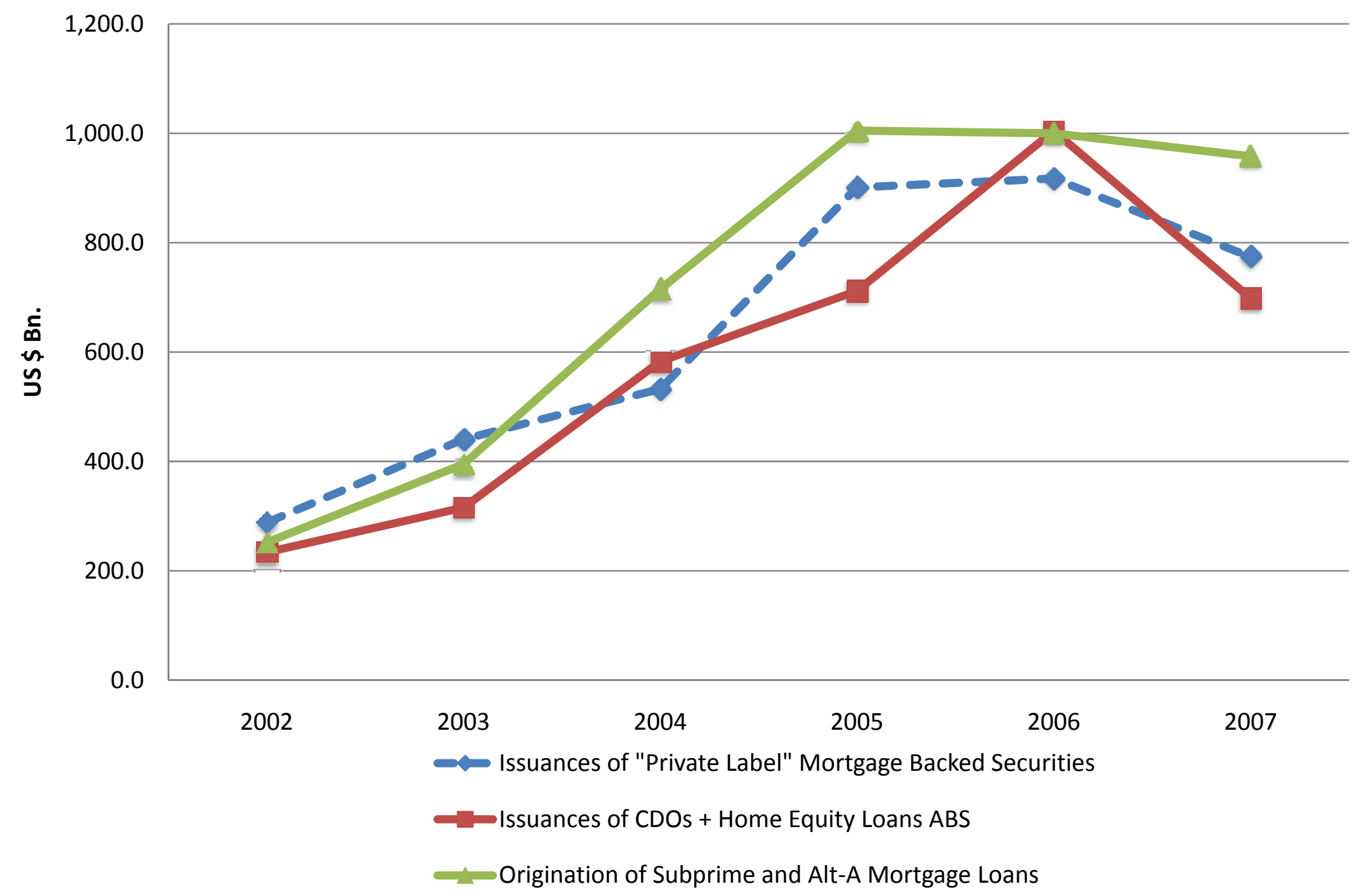




\section{Figure 4. Low Documentation and Zero Down Payment Mortgages}

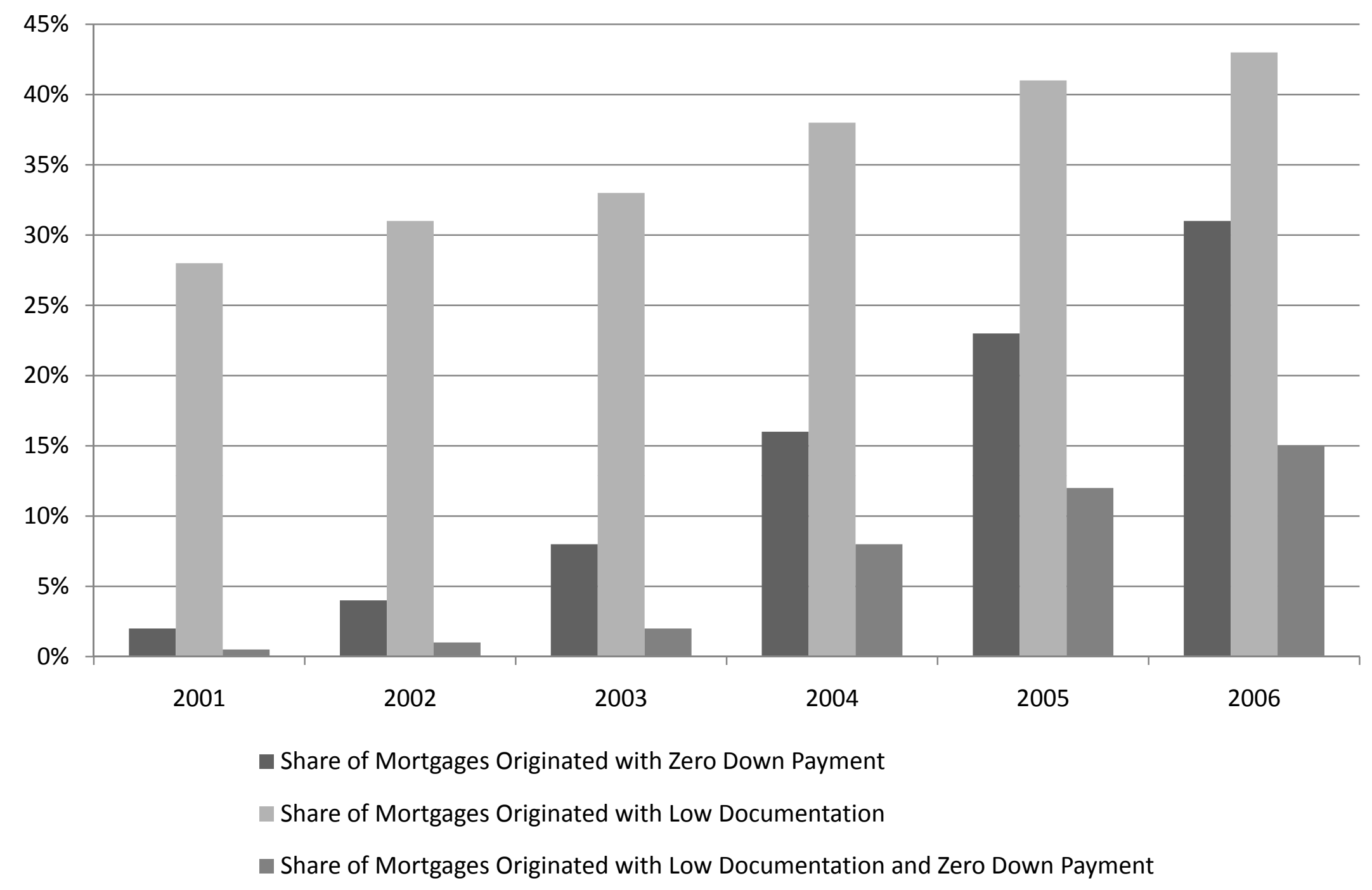




\section{Figure 5. New Century Borrowers}

Share of Borrowers with Stated Income.

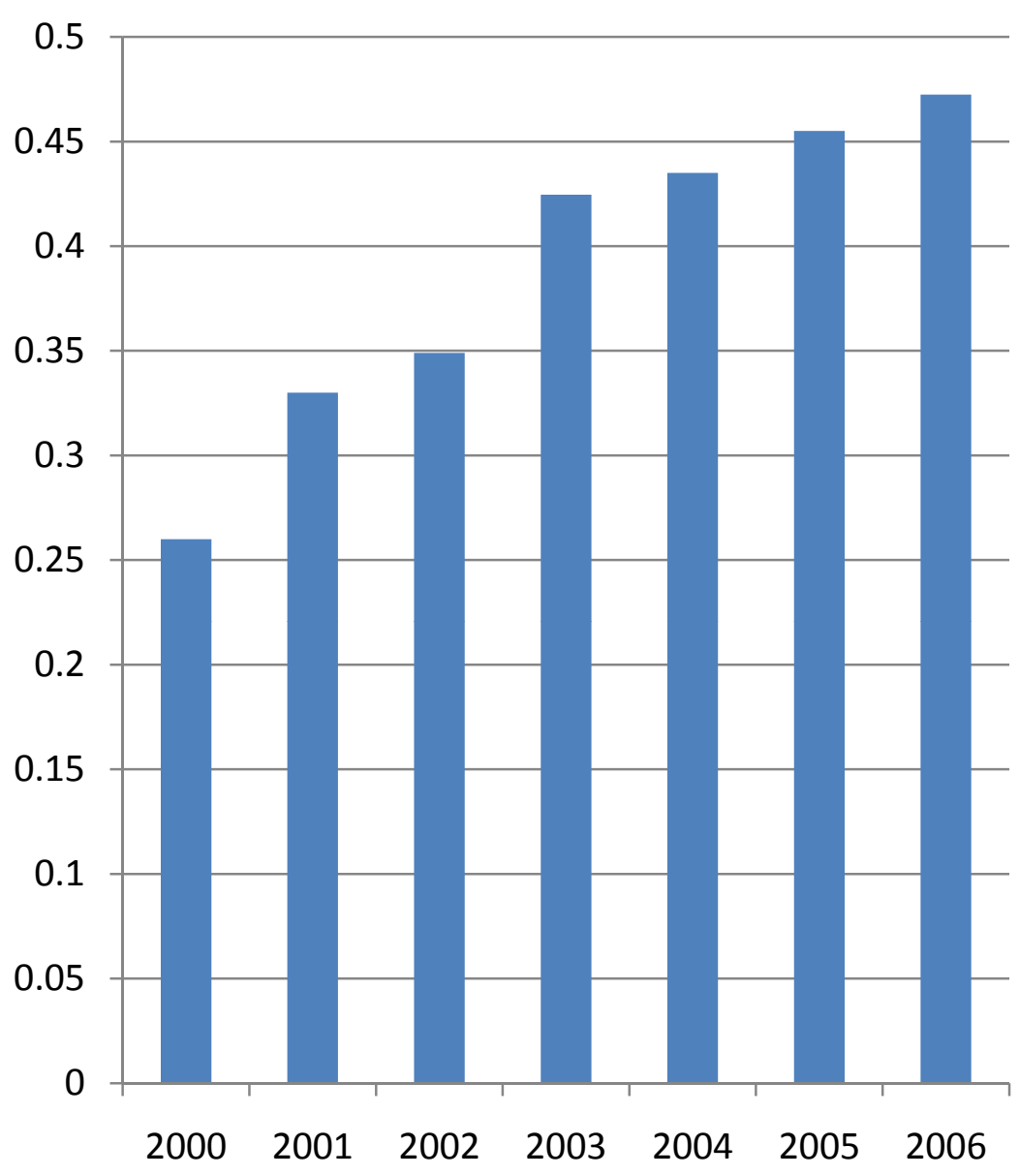

Mortgage Originated to Borrowers with Zero Down payment

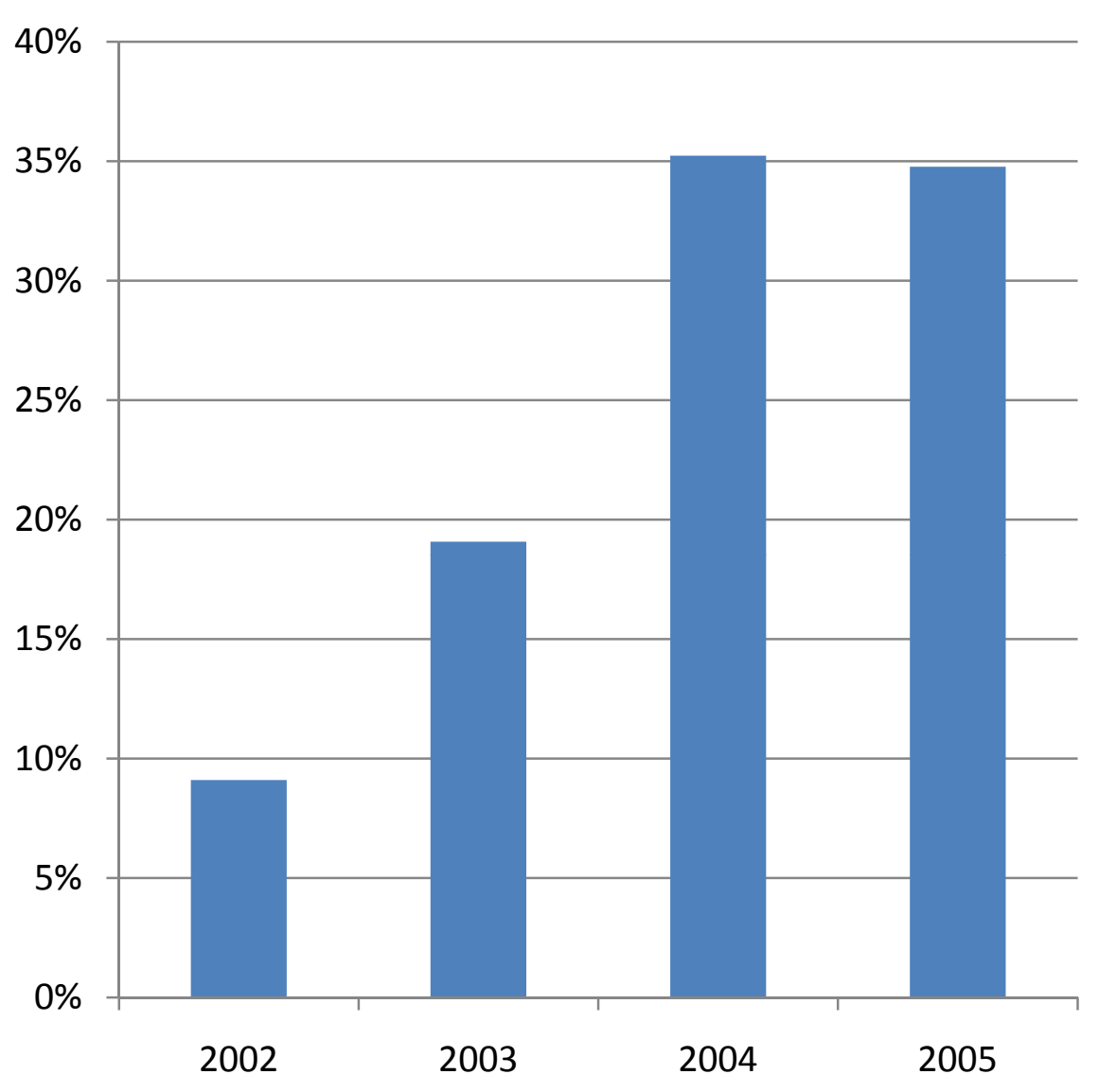


Figure 6. Prime/Conformable vs. Non-Prime Mortgages and Private Label MBS.

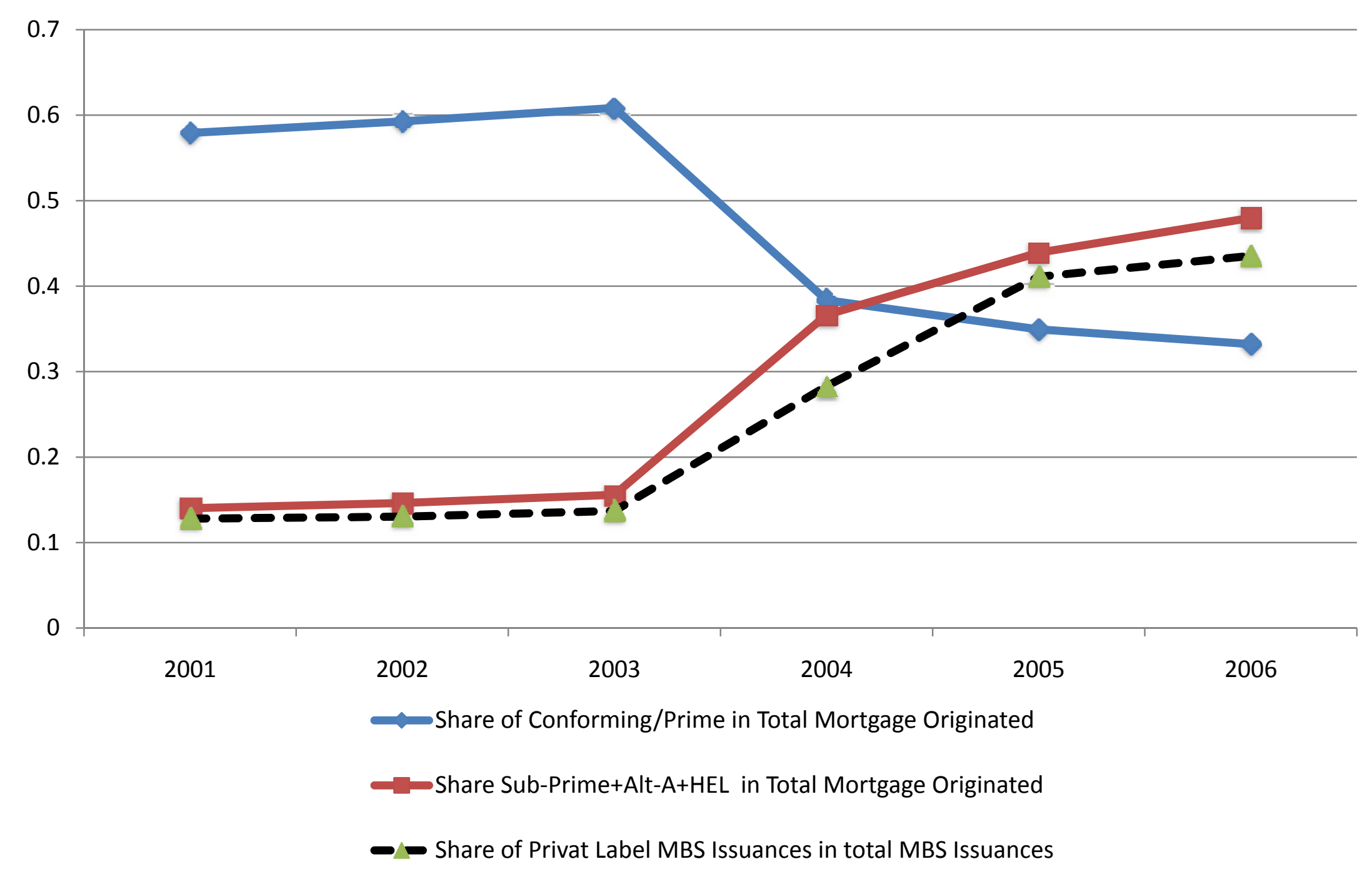




\section{Figure 7. Interest-Only+Option-ARM Originations and Spread on Mortgage}

Backed Securities

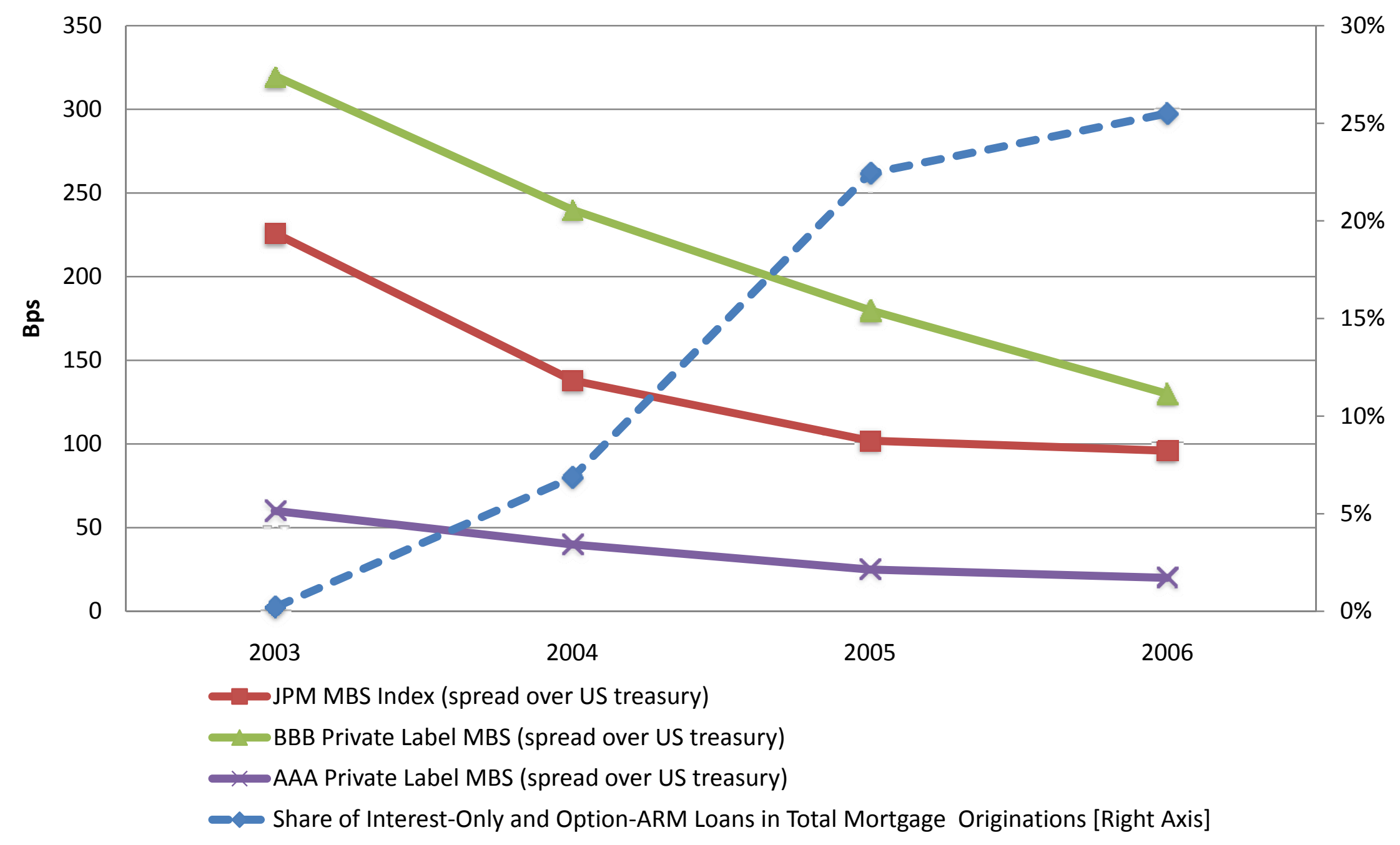


Figure 8. Subprime Loans Delinquency and CMBX Spread

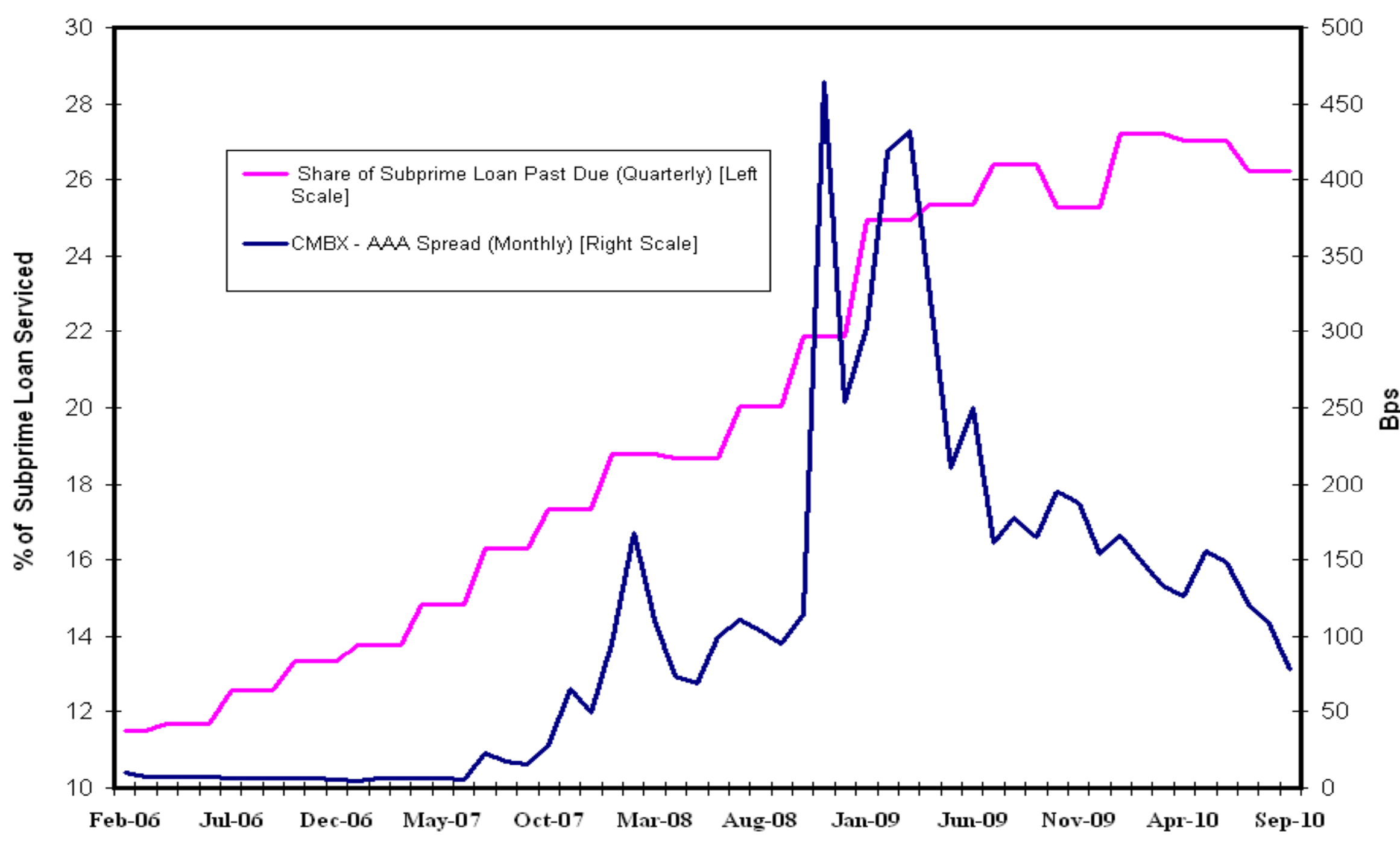

Source: JP Morgan and Mortgage Banker Association.

Note: The Markit ABX index is a synthetic tradeable index referencing a basket of 20 commercial and multi-family mortgage-backed securities allowing investors to take positions on commerical and multi-family mortgage-backed securities via CDS contracts. The CMBX spread is the Credit Default Swap protection premium implied by the CMBX index. 


\section{Figure 9. Subprime Loans Delinquency and CDOs Issuances}

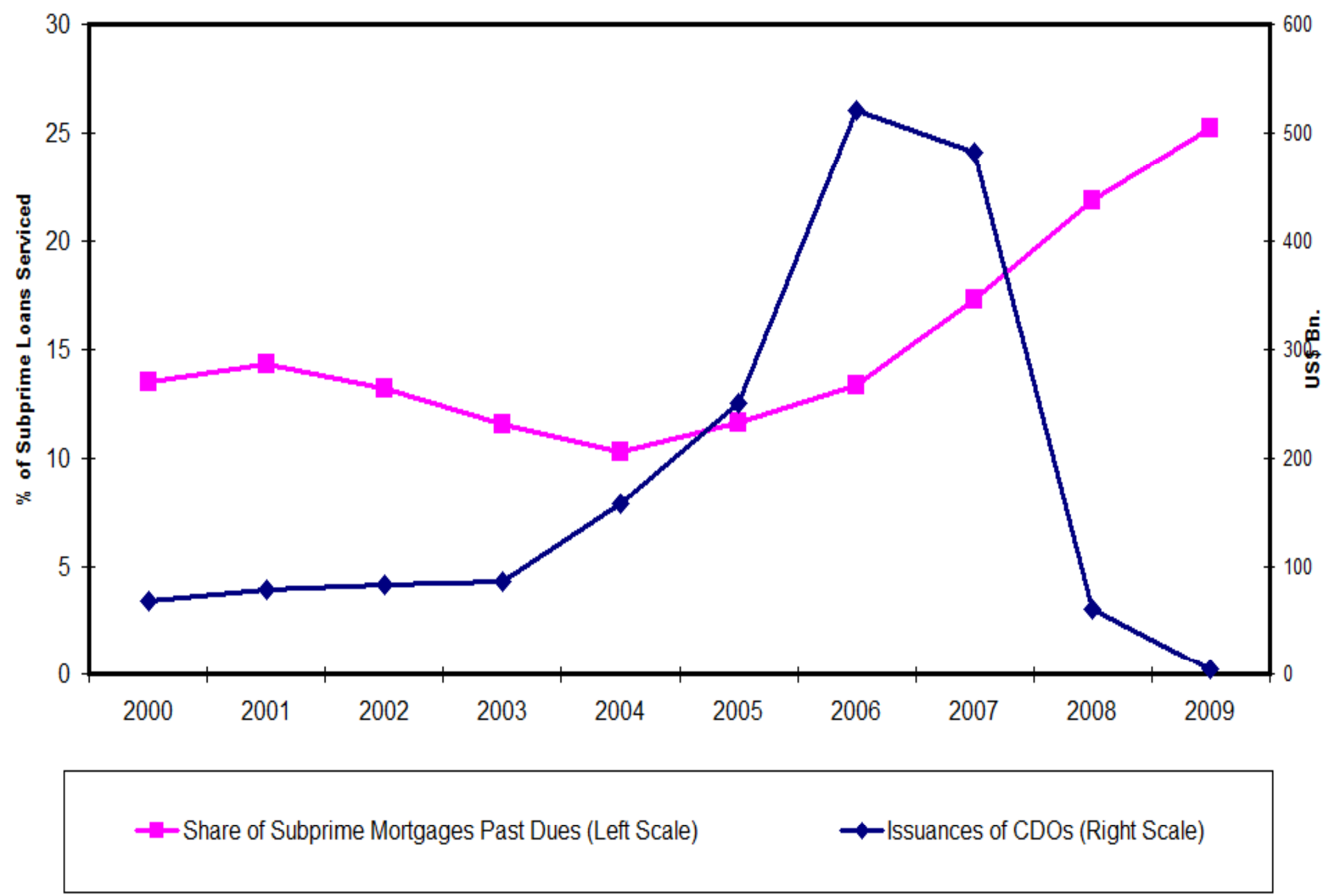




\section{Figure 10. Subprime Delinquency Rate and Subprime Originations}

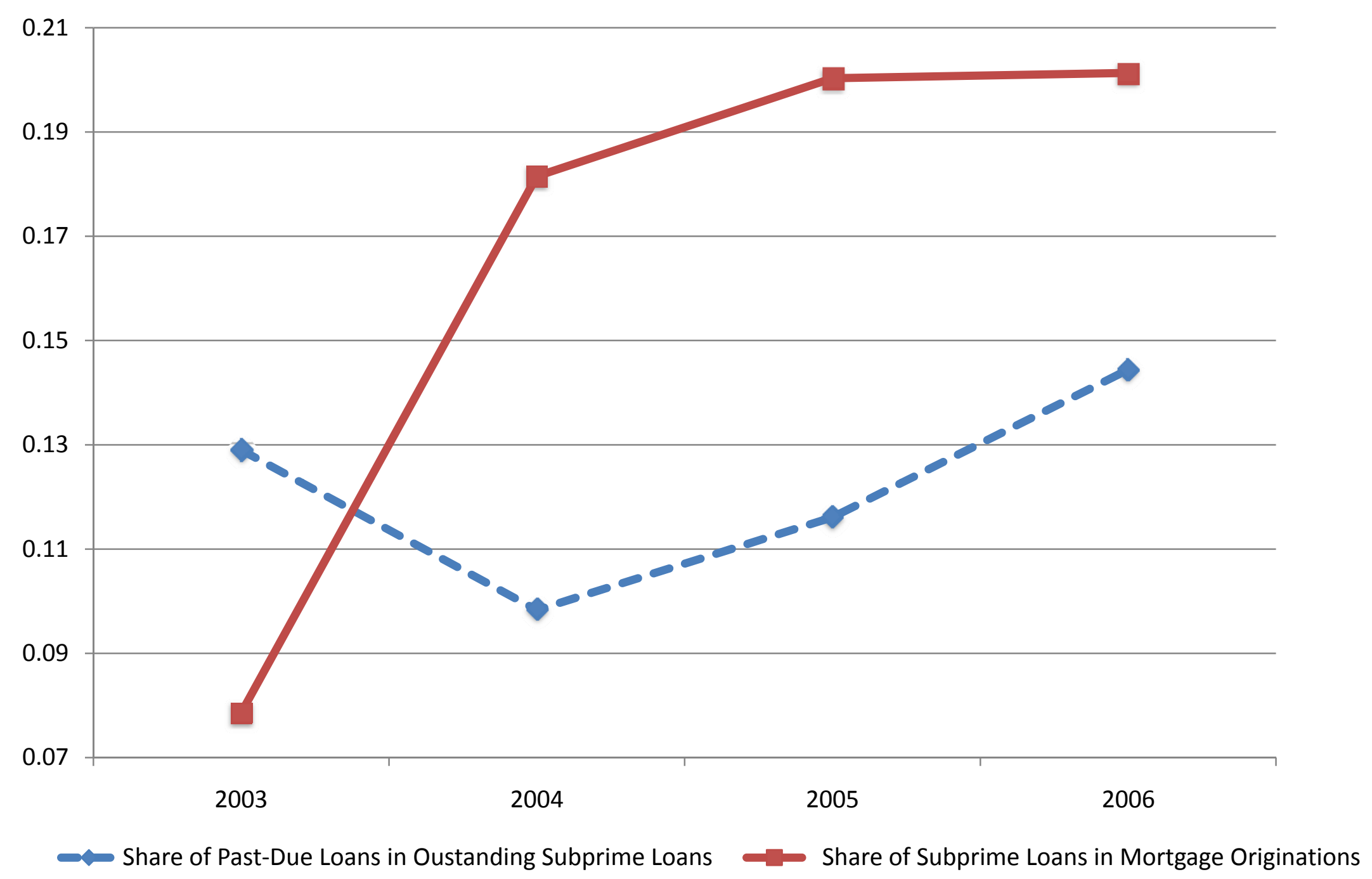




\section{Figure 11. Minority Borrowing and Home Ownership Rates.}

Share of Mortgage Borrowing by Race

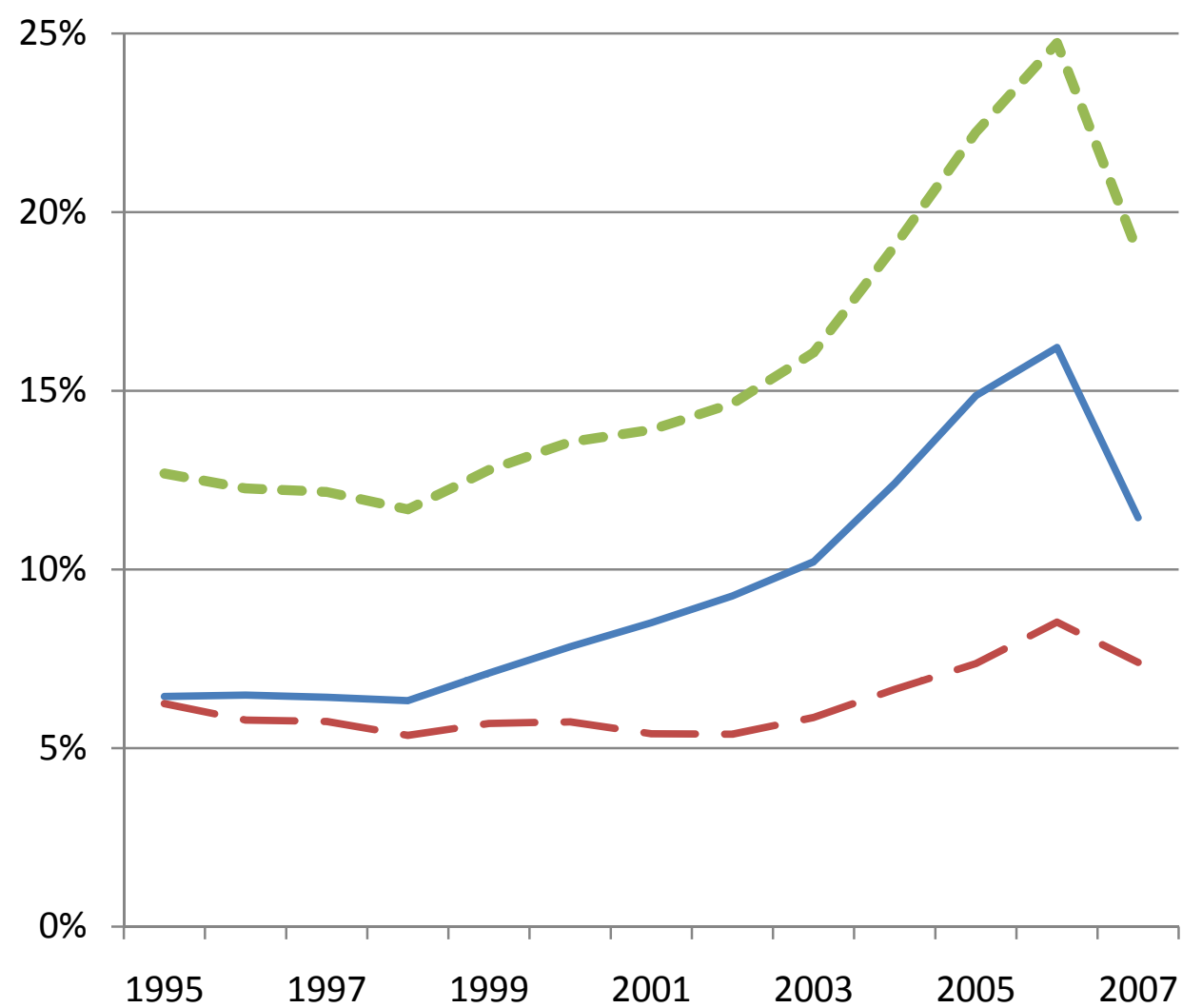

Share of Total Amount of Mortgages Issued Originated to Hispanics

- Share of Total Amount of Mortgages Issued Originated to African-American

- Share of Total Amount of Mortgages Issued Originated to Minorities (Hispanics+African American)

\section{Home Ownership by Race}

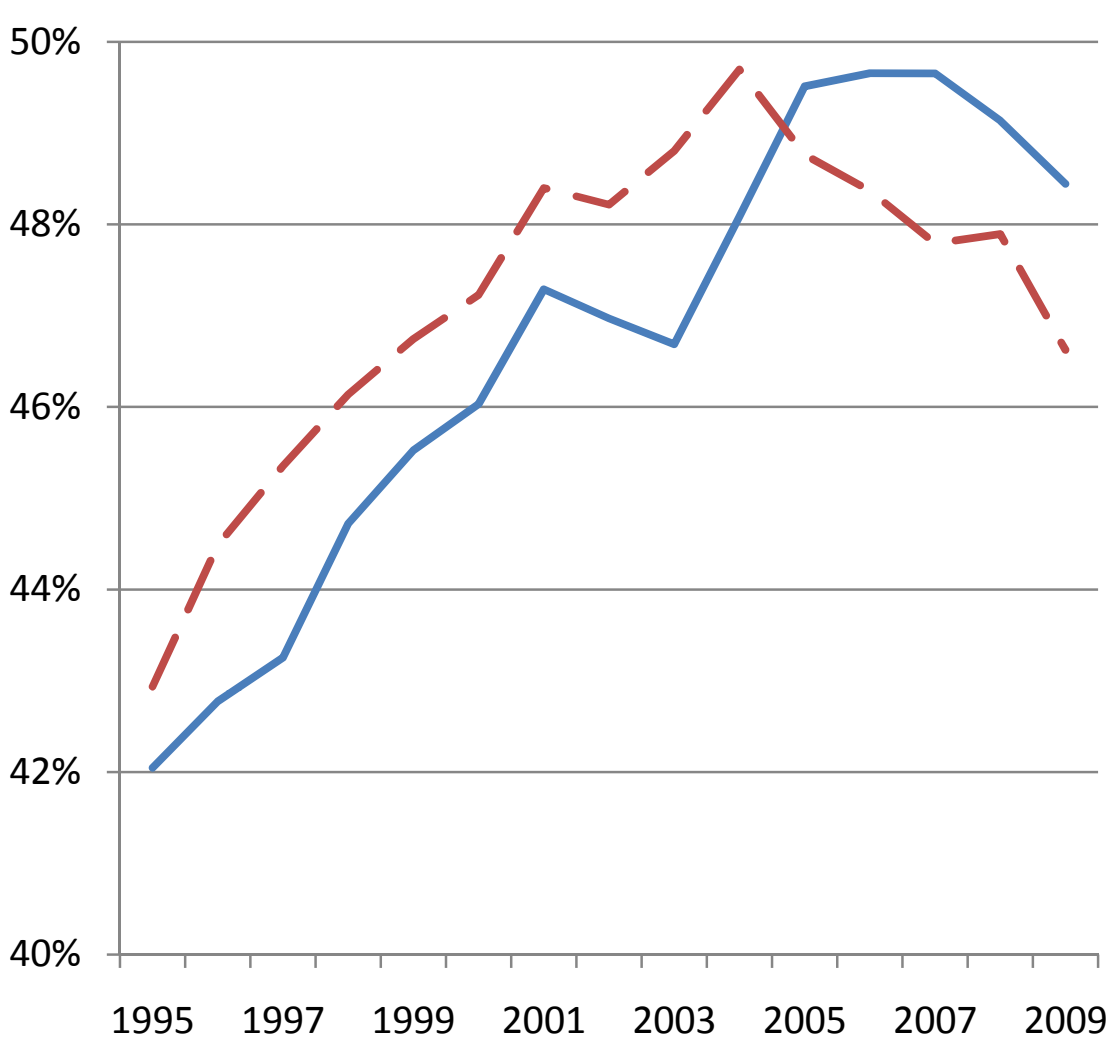

